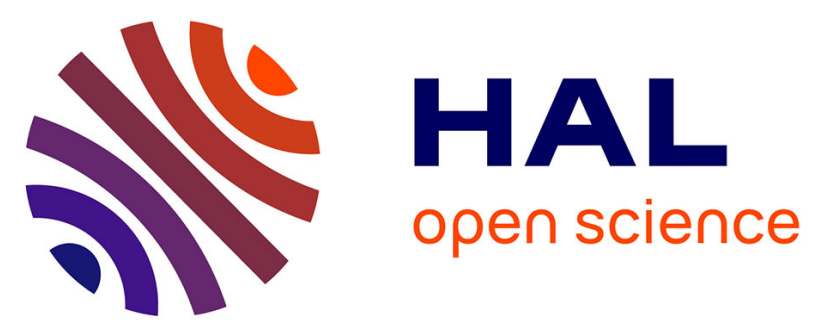

\title{
Siliceous phytoplankton production and export related to trans-frontal dynamics of the Almeria-Oran frontal system (western Mediterranean Sea) during winter
} Karine Leblanc, Bernard Queguiner, L. Prieur, Hervé Claustre, K. Oubelkheir, F. Bruyant

\section{To cite this version:}

Karine Leblanc, Bernard Queguiner, L. Prieur, Hervé Claustre, K. Oubelkheir, et al.. Siliceous phytoplankton production and export related to trans-frontal dynamics of the Almeria-Oran frontal system (western Mediterranean Sea) during winter. Journal of Geophysical Research. Oceans, 2004, 109, pp.C07010. 10.1029/2003JC001878 . hal-00702535

\section{HAL Id: hal-00702535 \\ https://hal.science/hal-00702535}

Submitted on 30 May 2012

HAL is a multi-disciplinary open access archive for the deposit and dissemination of scientific research documents, whether they are published or not. The documents may come from teaching and research institutions in France or abroad, or from public or private research centers.
L'archive ouverte pluridisciplinaire HAL, est destinée au dépôt et à la diffusion de documents scientifiques de niveau recherche, publiés ou non, émanant des établissements d'enseignement et de recherche français ou étrangers, des laboratoires publics ou privés. 


\title{
Siliceous phytoplankton production and export related to trans-frontal dynamics of the Almeria-Oran frontal system (western Mediterranean Sea) during winter
}

\author{
K. Leblanc and B. Quéguiner \\ Laboratoire d'Océanographie et de Biogéochimie, Campus de Luminy, Marseille, France \\ L. Prieur, H. Claustre, K. Oubelkheir, and F. Bruyant \\ Laboratoire d'Océanographie de Villefranche, CNRS-INSU et Université Pierre et Marie Curie, Villefranche-sur-Mer, France \\ Received 29 March 2003; revised 23 February 2004; accepted 16 April 2004; published 7 July 2004.
}

[1] A study of the biogeochemical properties of the Almeria-Oran front was carried out in December 1997 to January 1998. A strong salinity gradient between Atlantic and Mediterranean waters in the Alboran Sea allowed the differentiation of several subsystems: the Mediterranean waters, the frontal zone, and the anticyclonic gyre. Si and $\mathrm{C}$ biomass and production were clearly enhanced by the frontal dynamics on the Atlantic side of the jet while Mediterranean waters, which encountered severe nutrient depletion in the mixed layer, exhibited a typical oligotrophic regime. The distribution of particulate matter was controlled by a cross-frontal downwelling along the isopycnal slopes, that shoaled to the surface on the dense Mediterranean side and deepened toward the Atlantic side of the jet. A strong decoupling of production and biomass maximums occurred between the frontal limit, where particulate matter was produced, and the gyre, where it was accumulated. Export fluxes at $300 \mathrm{~m}$ were low at the frontal limit, representing $1-2 \%$ of surface $\mathrm{Si}$ and $\mathrm{C}$ production, and it is hypothesized that advective fluxes rather than grazing were the main factor limiting the accumulation of biomass. The adjacent systems, namely the associated anticyclonic gyre and the Mediterranean waters, were exporting Si to depth more efficiently than the frontal zone. The Si and $\mathrm{C}$ decoupling with depth appeared higher in the Almeria-Oran frontal system than in other open-ocean zones. The integrated Si production at the Almeria-Oran Front was $0.83 \mathrm{mmol}$ $\mathrm{Si} \mathrm{m} \mathrm{m}^{-2} \mathrm{~d}^{-1}$, which was closest to the production rates of mid-ocean oligotrophic gyres than of other frontal systems, and may be explained by the sampling period, which occurred in the winter season. INDEX TERMS: 4223 Oceanography: General: Descriptive and regional oceanography; 4243 Oceanography: General: Marginal and semienclosed seas; 4279 Oceanography: General: Upwelling and convergences; 4806 Oceanography: Biological and Chemical: Carbon cycling; KEYWORDS: Almeria-Oran front, Mediterranean Sea, Si cycle, diatoms, biogenic silica, Si uptake rates

Citation: Leblanc, K., B. Quéguiner, L. Prieur, H. Claustre, K. Oubelkheir, and F. Bruyant (2004), Siliceous phytoplankton production and export related to trans-frontal dynamics of the Almeria-Oran frontal system (western Mediterranean Sea) during winter, J. Geophys. Res., 109, C07010, doi:10.1029/2003JC001878.

\section{Introduction}

[2] The status of frontal zones as sites of enhanced primary production has been well documented in previous studies [Pingree et al., 1975; Simpson et al., 1982; Boucher et al., 1987; Traganza et al., 1987; Franks, 1992; Claustre et al., 1994a]. The mixing of two impoverished water bodies, characterized by strong differences in salinity or heat content, may generate hydrodynamic instabilities creating secondary ageostrophic vertical and horizontal movements [Kerr, 1986; Bower and Rossby, 1989; Arnone et al., 1990; Dewey et al., 1991; Tintoré et al., 1991]. As a

Copyright 2004 by the American Geophysical Union. 0148-0227/04/2003JC001878\$09.00 consequence, nutrients are upwelled in a relatively narrow region, inducing the fertilization of open-ocean frontal systems and allowing high accumulation of biomass as stated in the "ergocline theory" [Legendre and Le Fèvre, 1989]. The areal coverage of frontal zones is relatively narrow on a global scale, but it has been demonstrated through several studies that their impact in regional production budgets may be important [Boucher et al., 1987; Lohrenz et al., 1988a; Sournia et al., 1990; Franks, 1992; Claustre et al., 1994a].

[3] The existence of the Almeria-Oran Front (A-O Front), located in the eastern part of the Alboran Sea at the entrance of the Mediterranean Sea, was first established in 19851987 during the international Western Mediterranean Circulation Experiment [La Violette, 1988, 1989; Tintoré et al., 
1988; Arnone et al., 1990; Heburn and La Violette, 1990; Beckers and Nihoul, 1992]. A strong salinity gradient stretches out between Almeria (Spain) and Oran (Algeria) where the cold and fresh inflowing Atlantic jet meets the warmer and more saline Mediterranean waters, inducing a quasi-permanent geostrophic frontal structure, clearly visible on sea surface thermal and color satellite images [Arnone and La Violette, 1984, 1986; Wiesenburg and Arnone, 1986; Arnone and Wiesenburg, 1988; Lohrenz et al., 1988b; Morel and André, 1991; Ruiz et al., 2001]. The inflowing jet generates the formation of two anticyclonic gyres, the Eastern and the Western Alboran gyres (EAG and WAG) [Arnone et al., 1990; Folkard et al., 1994; Tintoré et al., 1988] and is then either re-entrained into the Alboran gyres or participates to the main flow of the Algerian Current (AC) along the North African coast [Arnone et al., 1990]. The WAG is a quasi-permanent feature and has been seen to collapse only on rare occasions (about 1 week per year), while the EAG is a much more dynamic structure and has been known to break down for longer time periods [Cheney and Doblar, 1982; Perkins et al., 1987; Heburn and La Violette, 1990]. The A-O Front location, determined by the position of the eastern branch of the EAG, is thus subject to strong temporal and spatial variability [Prieur and Sournia, 1994] and has been observed in its southernmost position along the $1000-\mathrm{m}$ isobath close to the Algerian coast [Salat et al., 1990; Prieur and Sournia, 1994; Allen et al., 2001] and up to $38^{\circ} \mathrm{N}$ in its northernmost position [Heburn and La Violette, 1990].

[4] Both satellite-derived information [Arnone and La Violette, 1984, 1986; Wiesenburg and Arnone, 1986; Arnone and Wiesenburg, 1988; Lohrenz et al., 1988b; Morel and André, 1991] and in situ measurements [Lohrenz et al., 1988a; La Violette, 1989; Gould and Wiesenburg, 1990; Prieur and Sournia, 1994; Claustre et al., 1994a; Fiala et al., 1994; Videau et al., 1994; Fielding et al., 2001; Ruiz et al., 2001] have detected anomalously high chlorophyll concentrations associated to the A-O Front. Extreme Chl $a$ concentrations of $23 \mu \mathrm{g} \mathrm{L}^{-1}$ in a band of narrow width $(6 \mathrm{~m})$ have been measured at $54 \mathrm{~m}$ depth in the A-O Front in November [Gould and Wiesenburg, 1990]. This amount of Chl $a$ is typical of highly productive coastal environments, such as the coast of Peru and West Africa, and is unusual for open-ocean systems, as was the monospecific nature of this bloom event. Indeed, up to $98 \%$ of the biomass was represented by the colonial centric diatom Thalassiosira partheneia, with a cell abundance of $1.10^{7}$ cells $\mathrm{L}^{-1}$. Several species of Thalassiosira, colonial and well adapted to low light, have been observed to bloom in other systems, such as upwellings zones, warm-core ring edges or the Antarctic iceedge, all having in common high turbulence and high nutrient availability [Gould and Wiesenburg, 1990]. Other studies have also emphasized the dominance of diatoms in the A-O Frontal region [Raimbault et al., 1993; Fiala et al., 1994; Claustre et al., 1994a, 1994b; Videau et al., 1994; Peinert and Miquel, 1994; Ruiz et al., 2001], confirming the opportunistic nature and the preferential growth of this phytoplankton group in highly turbulent and nutrient rich areas. Diatoms are thus considered a major component of the phytoplankton assemblages in frontal systems and are one of the key functional groups controlling primary production and organic matter export flux to depth.
[5] On the basis of the first available studies of this frontal structure in 1989, the FRONTAL group, part of JGOFS France, decided to undertake a case study of a frontal system in the A-O Front region in order to describe and quantify the secondary circulation pattern and to assess its potential enhancement effect on primary productivity [Prieur and Sournia, 1994]. The first cruise, Almofront I, was carried out during spring (April-May 1991), while the second campaign, Almofront II, was undertaken in winter (December 1996 to January 1997). The present article deals with the results of Almofront II and focuses on the coupled silicon and carbon cycles in the frontal system as compared to adjacent waters. The objectives of this paper are to investigate the cross-frontal exchanges of particulate matter and the interactions between the anticyclonic gyre and the Atlantic jet, to determine the factors that control diatom development in the frontal system, and to evaluate the A-O Front impact on the $\mathrm{Si}$ and $\mathrm{C}$ production and export budgets on a seasonal basis in the Western Mediterranean Sea.

\section{Material and Methods}

\subsection{Study Area and Sampling Strategy}

[6] Seawater samples were collected across the AlmeriaOran (A-O) Front (Figure 1a) in the eastern Alboran Sea $\left(0^{\circ}-3^{\circ} \mathrm{W} ; 35^{\circ} \mathrm{N}-36^{\circ} \mathrm{N}\right)$ during the second leg of the Almofront II cruise (22 December 1997 to 16 January 1998) on board R/V L'Atalante. The first leg (29 November to 21 December 1997) was devoted to a high-frequency sampling of the hydrological and biogeochemical characteristics of the frontal system [Sempéré et al., 2003]. The second leg aimed at describing the biological processes associated with the dynamical features already described on the first leg. This sampling strategy was also applied in May 1991 during the Almofront I cruise [Prieur and Sournia, 1994]. During the second leg, eight sites were chosen following an intensive 12-hour survey of the area using a continuous thermosalinometer and a vessel mounted ADCP (acoustic Doppler current profiler) RDI $75 \mathrm{kHz}$. Each site was replaced within the idealized structure of the A-O frontal system described in section 3.1. The depth of the main density isolines (between 27 and $28 \mathrm{~kg} \mathrm{~m}^{-3}$ ) and the direction and intensity of the horizontal currents were used to identify the position of each site relative to the jet. The hydrological features thus defined, the eight sites were located across the A-O Front, the associated anticyclonic gyre (AG), and the adjacent Mediterranean waters (Figure 1b). Process studies began at each site by the immersion of a floating mooring line, equipped with two PPS 5/2 sediment traps (at $100 \mathrm{~m}$ and $300 \mathrm{~m}$ ), subsequently followed by the ship for a period of 36 hours. Several CTD casts were repeated each day to detect any changes in water masses. Seawater was collected at discrete depths on a 0 - to 200-m layer with 12-L Niskin ${ }^{\circledR}$ bottles mounted on a Seabird ${ }^{B}$ SBE $911+$ CTD rosette sampler equipped with a Chelsea ${ }^{\mathbb{B}}$ Fluorimeter.

\subsection{Sample Treatment and Analysis}

\subsubsection{Bulk Parameters}

[7] Nitrate $\left(\mathrm{NO}_{3}\right)$, orthophosphate $\left(\mathrm{PO}_{4}\right)$, and orthosilicic acid $\left(\mathrm{Si}(\mathrm{OH})_{4}\right)$ were determined on a Technicon Autoanalyzer $^{(8)}$ following the protocol described by Strickland 
a

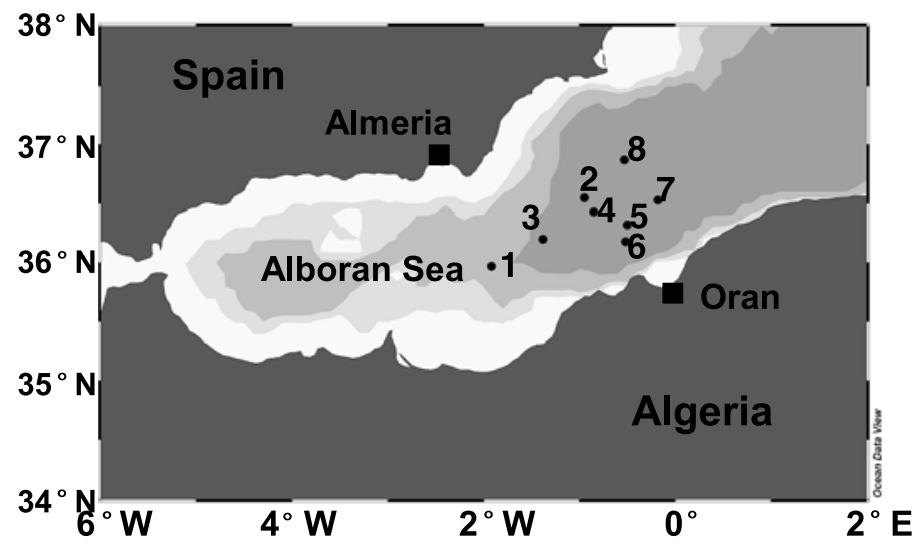

b

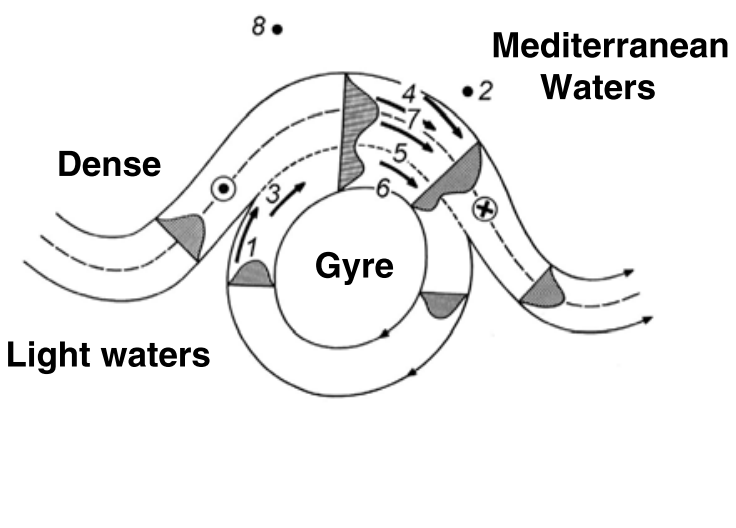

Figure 1. (a) Study area in the Alboran Sea and location of the eight study sites. (b) Schematic structure of the frontal system and repositioning of the study sites according to the hydrological feature. Shaded areas are proportional to the speed current.

and Parsons [1972]. The detection limit was $20 \mathrm{nM}$ for $\mathrm{PO}_{4}$ and $50 \mathrm{nM}$ for $\mathrm{NO}_{3}$ and $\mathrm{Si}(\mathrm{OH})_{4}$, and the precision was $0.01 \mu \mathrm{M}$.

[8] For particulate biogenic silica determinations, $1 \mathrm{~L}$ seawater was filtered onto $0.6-\mu \mathrm{m}$ polycarbonate membranes $\left(47 \mathrm{~mm}\right.$, Nucleopore $\left.{ }^{\mathrm{B}}\right)$. For the sediment trap material, a fraction of each sample (one eighth) was filtered onto $0.6-\mu \mathrm{m}$ polycarbonate membranes and treated as water column samples. Biogenic silica (BSi) was measured following the digestion of silica in hot $\mathrm{NaOH}$ for $45 \mathrm{~min}$ according to Nelson et al. [1989]. The precision of the method was $0.008 \mu \mathrm{mol} \mathrm{L}^{-1}$, and the detection limit was $0.010 \mu \mathrm{mol} \mathrm{L}^{-1}$.

[9] Seawater samples $(2.8$ L) were filtered onto Whatman ${ }^{B} \mathrm{GF} / \mathrm{F}$ membranes for pigment determination, and filters were preserved in liquid nitrogen. Total Chl $a$ and fucoxanthin concentrations were determined by HPLC using the protocol described by Vidussi et al. [1996]. Precision of the method averaged 5\% and the detection limit was $1-2 \mathrm{ng} \mathrm{L}^{-1}$.

[10] Seawater and sediment trap samples were filtered onto precombusted $\mathrm{GF} / \mathrm{F}$ membranes for particulate carbon determinations (PC), and samples were analyzed at the laboratory using a LECO $^{\mathbb{B}} 900$ carbon analyzer (see Claustre et al. [1999] for details).

\subsubsection{Silicon Uptake Rates and Primary Carbon Production}

[11] Dawn-to-dawn Si uptake experiments were conducted in simulated in situ conditions using on-deck incubation tanks cooled by running sea-surface water. Incubation depths were chosen and PAR (photosynthetically available radiation) levels (corresponding, respectively, to 50, 25, 15, 8,4 , and $1 \%$ of incoming surface light) were simulated using nickel screens. The depth of the euphotic layer (depth of the 1\% PAR level) was determined at each site using a SATLANTIC ${ }^{\circledR}$ in-water radiometer and estimated with an uncertainty of 1 to $2 \mathrm{~m}$. Before dawn, $275 \mathrm{~mL}$ of seawater were sampled and spiked with $2500 \mathrm{~Bq}(0.068 \mu \mathrm{Ci})$ of the radioactive isotope silicon-32 $\left({ }^{32} \mathrm{Si}\right)$, which specific activity was $42.2 \mathrm{kBq} \mu \mathrm{g} \mathrm{Si}{ }^{-1}$. For all samples, $\mathrm{Si}$ addition did not exceed $1 \%$ of the initial concentration. After incu- bation, samples were filtered on polycarbonate Nucleopore membrane $(0.6 \mu \mathrm{m}, 47 \mathrm{~mm})$. Filters were rinsed with filtered $(0.2 \mu \mathrm{m})$ seawater, and placed in scintillation vials. The ${ }^{32} \mathrm{Si}$ uptake was measured in a Packard ${ }^{\mathbb{B}} 1600$-TR scintillation counter by Cerenkov effect, following the method described by Tréguer et al. [1991] and Leynaert et al. [1993]. Precision of the method averages $10 \%$. Si specific uptake rates VSi (in $\mathrm{d}^{-1}$ ) have been derived from BSi $\left(\mu \mathrm{mol} \mathrm{L}^{-1}\right)$ and absolute

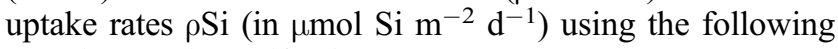
equation: $\mathrm{VSi}=\rho \mathrm{Si} / \mathrm{BSi}$.

[12] P versus I curves were used to determine the phytoplankton photosynthetic parameters of carbon fixation versus irradiance. Samples were inoculated with ${ }^{14} \mathrm{C}$ $\left(\mathrm{NaH}^{14} \mathrm{CO}_{3}, 0.4 \mu \mathrm{Ci} / \mathrm{mL}\right)$ and exposed to different light levels in a radial photosynthetron [Babin et al., 1994]. The maximum chlorophyll-specific carbon fixation rates $\mathrm{P}_{\max }^{B}\left(\mathrm{mg} \mathrm{C}(\mathrm{mgChl} a)^{-1} \mathrm{~h}^{-1}\right)$ were estimated by fitting the expression proposed by Platt et al. [1980] to the raw data of carbon fixation versus irradiance. Primary carbon production was calculated according to the model proposed by Morel et al. [1996].

\section{Results}

\subsection{Hydrological and Nutrients Status}

[13] The location of each site was not predetermined by geographical coordinates, but as relative position in the jeteddy system as shown in Figure 1b. For a better visualization of the interactions between the A-O Front, the Atlantic Anticyclonic Gyre (AG), and the Mediterranean waters, the different sites were relocated along a pseudo-transect, showing the gradual transition between the Mediterranean and the Atlantic side of the jet. The position of each site along this pseudo-transect was chosen according to the density gradient and current speed. The physical distances between sites are in the order of 4 to $10 \mathrm{~km}$, but are difficult to determine with accuracy once the sites are relocated on the idealized jet-gyre structure (Figure 1b). For the purpose of this paper, all sites have been arbitrarily placed at equal distance from one another. The contour plots presented (Figures 2 and 3) should therefore be considered as "virtual 

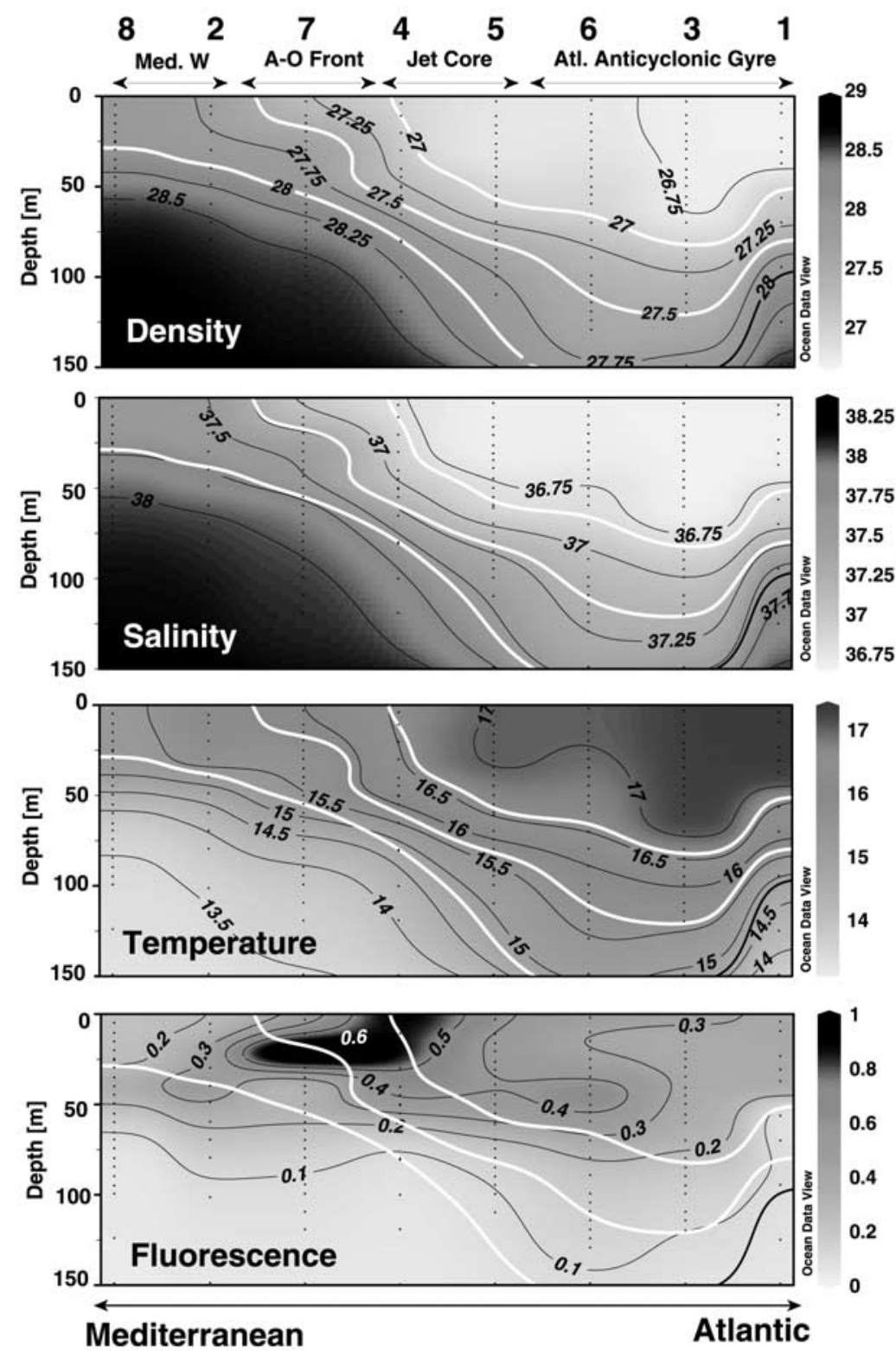

Figure 2. Vertical contour plots of density $\left(\mathrm{kg} \mathrm{m}^{-3}\right)$, salinity (PSU), temperature $\left({ }^{\circ} \mathrm{C}\right.$, Celsius), and fluorescence (arbitrary unit) along the pseudo-transect across the A-O frontal system from the Mediterranean side (left) to the Atlantic side (right). The density isolines (27, 27.5, and 28) are reported on all figures. Freeware used for plotting: Ocean Data View (from R. Schlitzer, 2003, available at http:// www.awi-bremerhaven.de/GEO/ODV). See color version of this figure in the HTML.

sections" of the A-O Front system. The following interpretation of the results of the pseudo-transect seems, however, well adapted since a CTD section realized across the front between the sampling of sites 7 and 8 showed the same plots of density, Chl $a$, and nutrients as in our virtual transect (data not shown). The shape of the isopycnals also matched those of the transect obtained during the first leg, through high-frequency sampling across the front [Sempéré et al., 2003, Figure 3].

[14] The repeated CTD casts during the process studies confirmed that the intersite variability was much higher than the intrasite variability (data not shown), allowing a clear distinction between sites according to the hydrological features. CTD profiles of temperature, salinity, potential density anomaly, and fluorescence displayed the variable influence of Atlantic and Mediterranean waters, the latter being colder (in winter conditions), saltier, and poorer in nutrients than the Atlantic ones (Figures 2 and 3). The sites located in the anticyclonic gyre and in the jet were representative of low-density Modified Atlantic Waters (MAW) $\left(<27 \mathrm{~kg} \mathrm{~m}^{-3}, \mathrm{~S}<36.7\right)$. The highest horizontal velocities were associated with the lighter density-field, confirming that the core of the jet was located on the Atlantic side [Claustre et al., 2000]. Site 7 exhibited the steepest density gradient, showing a rapid transition from Atlantic to Mediterranean waters (between 27 and $27.5 \mathrm{~kg} \mathrm{~m}^{-3}$ ), and was 

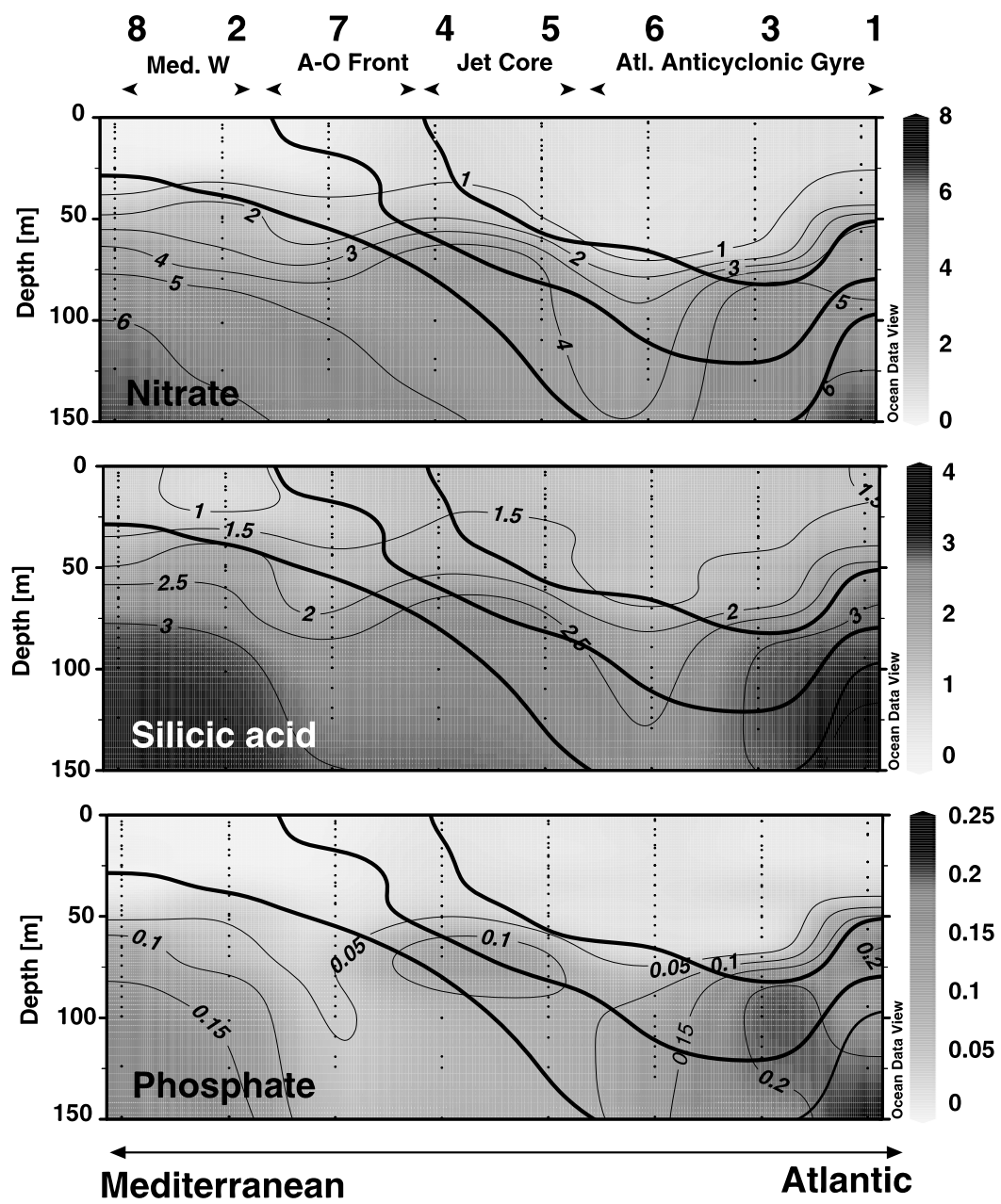

Figure 3. Vertical contour plots of $\mathrm{NO}_{3}, \mathrm{Si}(\mathrm{OH})_{4}$, and $\mathrm{PO}_{4}$ concentrations (in $\mu \mathrm{M}$ ) along the same transect as in Figure 2. See color version of this figure in the HTML.

defined as the frontal limit. Sites 4 and 5 were located on the left and right side of the jet core, respectively, and were characterized by high stream velocities $\left(60 \mathrm{~cm} \mathrm{~s}^{-1}\right)$. Sites 6 , 3 , and 1 were positioned toward the center of the AG and showed a marked increase of the mixed layer depth. Sites 2 and 8 were typical of Mediterranean waters with the highest surface densities (27.7 to $27.9 \mathrm{~kg} \mathrm{~m}^{-3}$ ) and salinities (37.537.6) at the surface level. Mediterranean waters were more stratified, with a shallower mixed layer of $\sim 25 \mathrm{~m}$, as compared to 60 to $100 \mathrm{~m}$ for Atlantic waters (Table 1).

[15] The Mediterranean surface waters sites (sites 2, 8) were severely depleted in all nutrients (Figure 3 ). $\mathrm{PO}_{4}$ concentrations remained under the limit of detection $(<0.02 \mu \mathrm{M})$ in the top $40 \mathrm{~m}$, while $\mathrm{NO}_{3}$ concentrations were low but detectable $(0.03-0.06 \mu \mathrm{M})$ in the first $20 \mathrm{~m}$. Surface $\mathrm{Si}(\mathrm{OH})_{4}$ values were also among the lowest observed and were as low as $0.8 \mu \mathrm{M}$ at site 2 in the first $20 \mathrm{~m}$. The depth of the nitracline shoaled between 50 and $90 \mathrm{~m}$ on the Atlantic side of the jet (in the AG) and shoaled to $30 \mathrm{~m}$ on the Mediterranean side, following the variations in the mixed layer depth (Table 1). The nutrient signature differed at site 4, showing a first shallow nitracline at $25 \mathrm{~m}$, followed by a nutrient impoverished layer between 75 and $125 \mathrm{~m}$ (clearly visible for $\mathrm{PO}_{4}$ and $\mathrm{NO}_{3}$ ) and by a new increase when the dense Mediterranean waters were encountered.
The same impoverished layer was encountered at site 7 below $50 \mathrm{~m}$. This sharp anomalous decrease, particularly obvious on $\mathrm{PO}_{4}$ concentrations, was explained by a downwelling of surface Mediterranean waters, impoverished with nutrients, along the isopycnal slopes.

[16] Integrated $\mathrm{N} / \mathrm{P}$ and $\mathrm{Si} / \mathrm{N}$ nutrient ratios were calculated over the euphotic layer $\left(0-Z_{\mathrm{e}}\right)$ and compared with the ratios obtained from $Z_{\mathrm{e}}$ to $200 \mathrm{~m}\left(\mathrm{Z}_{\mathrm{e}}-200\right)$ in order to assess the nutritive potential of deep waters (Figure 4). Nutrient deficiency was estimated as compared to the phytoplankton nutrient requirements, expected to be in the following molar ratios: Si:N:P = 16:16:1, according to Redfield et al. [1963] and Brzezinski [1985]. The nutrient ratios showed contrasting situations: in the euphotic layer, $\mathrm{N} / \mathrm{P}_{(0-\mathrm{Ze})}$ ratios exhibited a severe $\mathrm{PO}_{4}$ deficiency, with values ranging from

Table 1. Depths of the Mixed Layer $\left(Z_{m}\right)$, the Euphotic Layer $\left(Z_{\mathrm{e}}\right)$, and the Nutricline $\left(\mathrm{Z}_{\mathrm{n}}\right)$

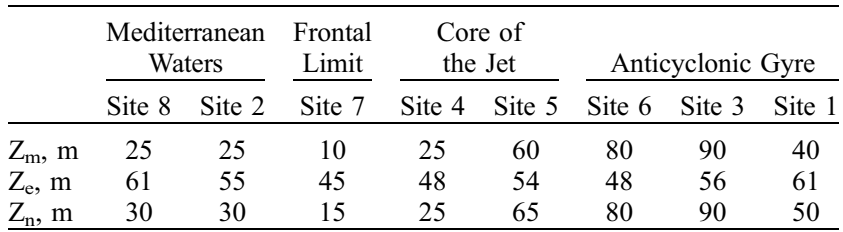



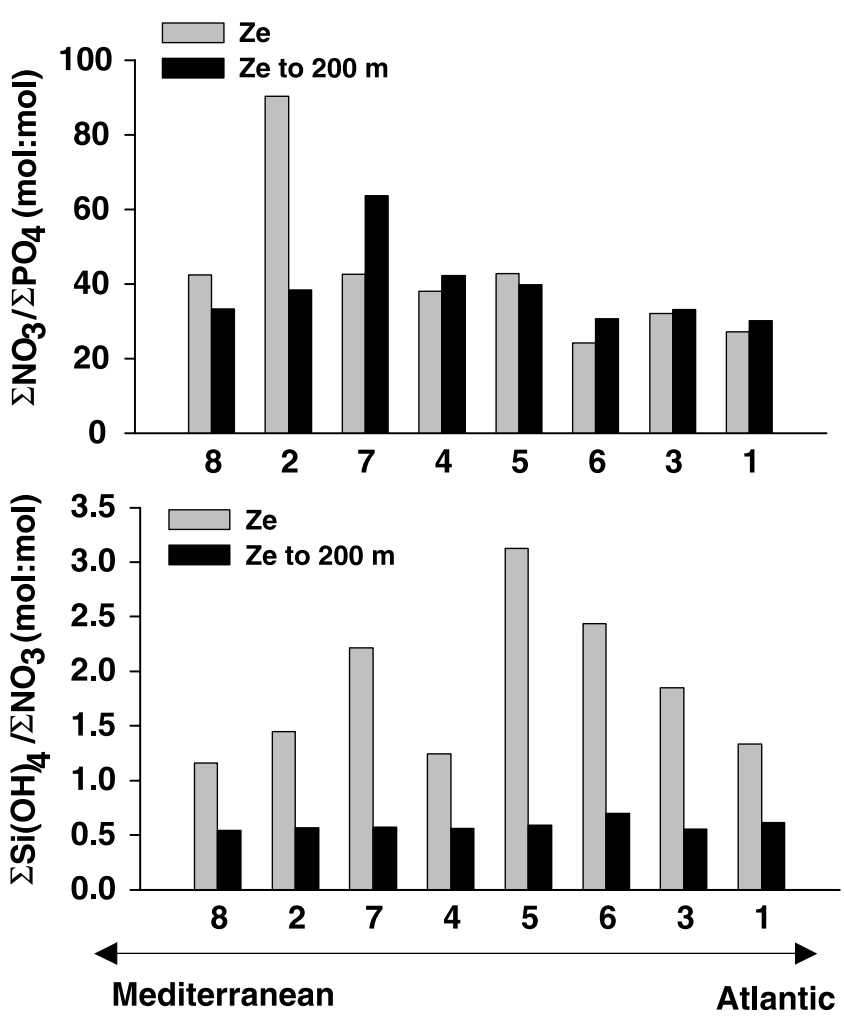

Figure 4. Integrated $\mathrm{NO}_{3} / \mathrm{PO}_{4}$ and $\mathrm{Si}(\mathrm{OH})_{4} / \mathrm{NO}_{3}$ ratios over the euphotic layer $\left(\mathrm{Z}_{\mathrm{e}}\right)$ and between the euphotic layer and $200 \mathrm{~m}\left(\mathrm{Z}_{\mathrm{e}}-200\right)$.

24 at site 6, which is the mean for the Mediterranean Sea [McGill, 1965], up to 90 at site $2 . \mathrm{Si} / \mathrm{N}_{(0-Z e)}$ ratios were always higher than $1(1.2-3.1)$, reflecting a deficiency of nitrate over silicon. The $\mathrm{P}$ deficiency remained important below the euphotic layer, with high ratios at all sites (3363 ). The reverse situation occurred for $\mathrm{Si}$ versus $\mathrm{N}$ availability: The integrated $\mathrm{Si} / \mathrm{N}_{(\mathrm{Ze}-200)}$ ratio fell below 1 at all sites, with values between 0.5 and 0.7 , reflecting a shift toward systematic Si deficiency below the euphotic layer.

\subsection{Cross-Jet Distribution of Particulate Matter}

[17] Vertical distributions of particulate matter (Chl $a$, fucoxanthin, biogenic silica and particulate carbon) are illustrated in Figure 5. The Mediterranean sites (sites 8, 2) clearly showed the lowest particulate matter concentrations. Chl $a$ ranged between 0.23 and $0.45 \mu \mathrm{g} \mathrm{L}^{-1}$ and was rather homogeneously distributed in the surface layer, yet exhibited a slight maximum at the bottom of the mixed layer (around $50 \mathrm{~m}$ ). Fucoxanthin, a pigment found in Bacillariophyceae (diatoms) and occasionally in Prymnesiophyceae and Chrysophyceae, was close to the detection limit at the Mediterranean sites (sites 2, 8). This was paralleled by very low BSi concentrations, which ranged from 0.02 to $0.10 \mu \mathrm{mol} \mathrm{L}^{-1}$ in the mixed layer. Particulate carbon (PC) concentrations were likewise lower than at the Atlantic sites, and varied between 3.6 and $6.3 \mu \mathrm{mol} \mathrm{L}^{-1}$. All biomass parameters were significantly higher at the frontal limit (site 7) and exhibited a marked maximum at the subsurface $(15 \mathrm{~m})$. Chl $a$, fucoxanthin, BSi and PC exhibited the highest concentrations encountered during the cruise with values as high as $2.43 \mu \mathrm{g} \mathrm{L}^{-1}, 1.51 \mu \mathrm{g}$ $\mathrm{L}^{-1}, 0.62 \mu \mathrm{mol} \mathrm{L}{ }^{-1}$, and $12.8 \mu \mathrm{mol} \mathrm{L}{ }^{-1}$, respectively. On the Atlantic side of the jet, particulate matter concentrations decreased slightly but showed a distinct accumulation in the core of the jet and at site 6 in the AG, together with an increase of the depth of the biomass maximum, following the increase in the mixed layer (Table 1). At site 6 , the biomass maximum was located around $50 \mathrm{~m}$, but nonnegligible concentrations were still found at $150 \mathrm{~m}(\mathrm{Chl}$ a: $0.15 \mu \mathrm{g} \mathrm{L}^{-1}$, fucoxanthin: $0.08 \mu \mathrm{g} \mathrm{L}^{-1}, \mathrm{BSi}: 0.14 \mu \mathrm{mol}$

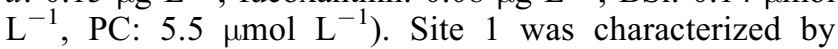
moderate Chl $a$, fucoxanthin, and PC values in the first $50 \mathrm{~m}$, while site 3 presented low biomass values over the entire water column.

[18] Integrated particulate matter stocks over $200 \mathrm{~m}$ (PC, $\mathrm{BSi}, \mathrm{Chl} a$, and fucoxanthin) are plotted on the cross-frontal virtual transect in Figure 6. Particulate carbon and Chl $a$ followed the same trend, with the lowest stocks encountered at the Mediterranean sites (sites 2, 8) as well as in the jet core (sites 4,5$)$. Integrated stocks were intermediate at the frontal limit (site 7) and highest in the AG (sites 1, 3, 6). The highest integrated $\mathrm{BSi}$ and fucoxanthin stocks were observed at the frontal limit (site 7) and on the right side of the jet (site 6), while low values were encountered in adjacent waters. On the Mediterranean side, site 2 (which was closest to the front) exhibited higher pigment integrated stocks as compared to site 8 . Integrated $\Sigma B \mathrm{BSi} / \Sigma \mathrm{PC}$ ratios (Figure 6) were higher across the front, from the frontal limit (site 7) to the edge of the AG (site 6). The $\Sigma B S i / \Sigma P C$ ratios varied from 0.020 to 0.034 at these sites $(7,4,5,6)$ and were lower in adjacent waters (sites 1, 3 and 2,8) with values ranging between 0.010 and 0.015 .

[19] The vertical distribution of $\mathrm{C}$ and $\mathrm{Si}$ uptake rates exhibited different patterns along the Mediterranean-Atlantic gradient. Primary production (Figure 7) was highest on the Atlantic side of the jet (sites 1 to 7 ), with $\mathrm{C}$ uptake rates ranging between 0.65 to $1.75 \mu \mathrm{mol} \mathrm{C} \mathrm{L} \mathrm{C}^{-1} \mathrm{~d}^{-1}$ in the surface layer, whereas the Mediterranean sites (sites 2,8) again

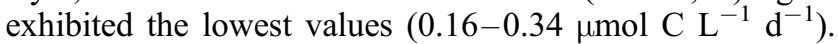
The frontal limit (site 7) exhibited the same feature as for particulate matter (Figure 5) with a sharp increase at the subsurface $(15 \mathrm{~m})$. However, the highest primary production rates were observed in the core of the jet, near the frontal limit at site 4 , with a maximum value of $1.75 \mu \mathrm{mol} \mathrm{C} \mathrm{L} \mathrm{C}^{-1} \mathrm{~d}^{-1}$.

[20] The Si uptake rates $(\rho \mathrm{Si})$ were extremely low at all sites (Figure 7), with a maximum uptake rate as low as 60 nmol Si L ${ }^{-1} \mathrm{~d}^{-1}$ (site 4), which coincided with the maximum $\mathrm{C}$ uptake rate. The $\rho \mathrm{Si}$ did not exhibit any increase at the subsurface at the frontal limit (site 7) like all other parameters but showed a small increase at $40 \mathrm{~m}$ (Figure 7). Elsewhere, surface values of $\rho \mathrm{Si}$ were generally lower than $20 \mathrm{nmol} \mathrm{Si} \mathrm{L}{ }^{-1} \mathrm{~d}^{-1}$.

[21] It should be noted that the ship drifted slightly between day 1 and 2 at site 7 from the frontal limit toward the inner part of the jet where the biomass encountered was much lower than on the first day. Particulate matter parameters were sampled on the first day, while production rates were measured on the second day. Subsequently, primary production and $\mathrm{Si}$ uptake rates were very likely to be underestimated at site 7 , and may not be representative of the frontal limit. It is hypothesized that if primary production measurements had been done on the first day, the 

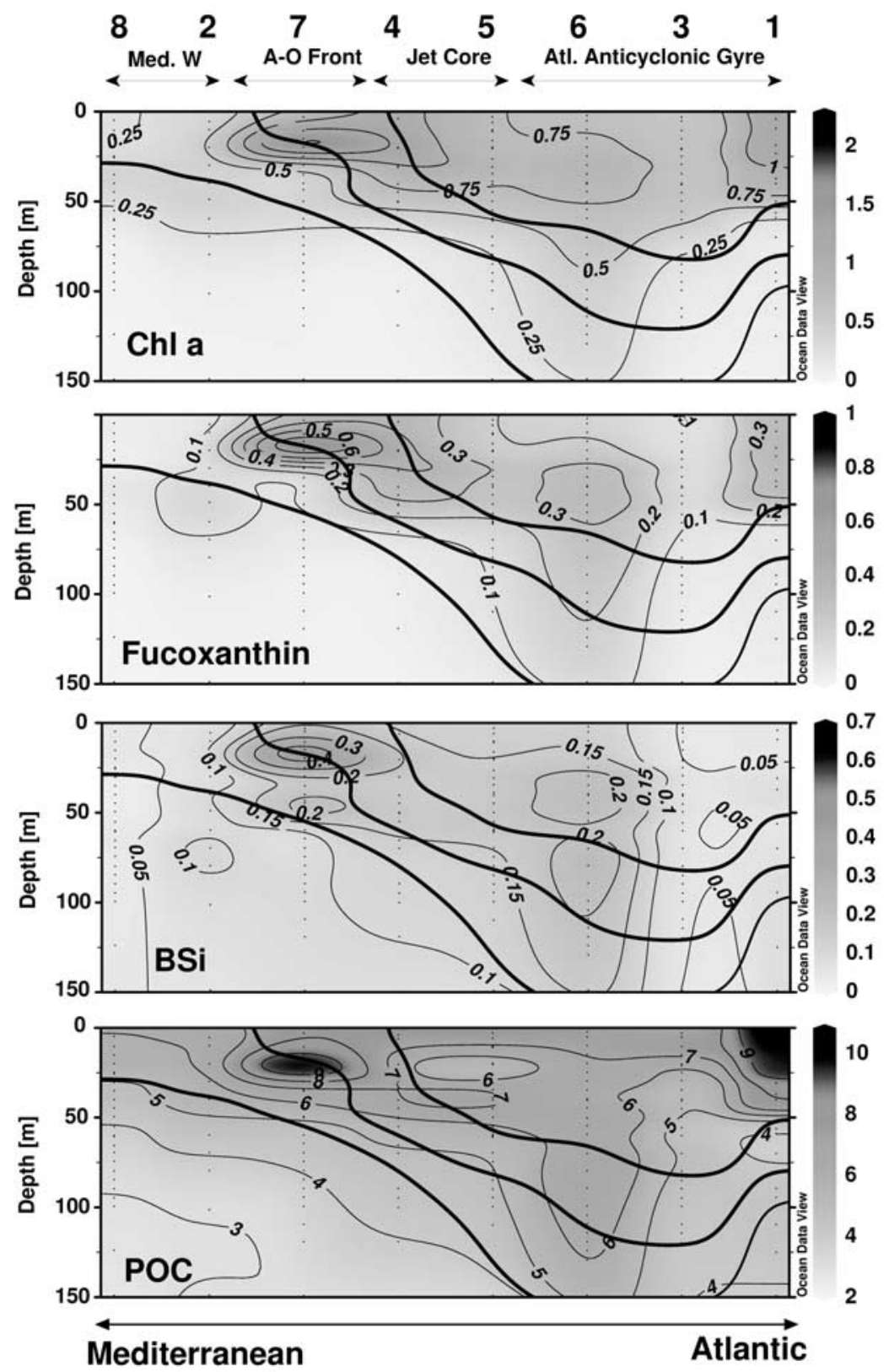

Figure 5. Vertical contour plots of particulate matter (chlorophyll $a$ and fucoxanthin in $\mu \mathrm{g} \mathrm{L}^{-1}$, biogenic silica (BSi), and particulate carbon (PC) in $\mu \mathrm{mol} \mathrm{L}^{-1}$ ) along the same transect as in Figure 2. See color version of this figure in the HTML.

frontal limit would have displayed the highest values of the pseudo-transect in accordance to the location of the peak of biomass.

[22] Integrated $\mathrm{Si}$ and $\mathrm{C}$ production rates (over $\mathrm{Z}_{\mathrm{e}}$ ) were plotted in Figure 8. Interestingly, integrated production rates did not exactly follow the same trend as the integrated biomass distribution. Integrated primary production $(\Sigma \rho \mathrm{C})$ ranged from 12 to $42 \mathrm{mmol} \mathrm{C} \mathrm{m}^{-2} \mathrm{~d}^{-1}$; the lowest values were found at the Mediterranean sites and increased by a factor 3 in the core of the jet. Integrated $\mathrm{Si}$ uptake rates $(\Sigma \rho \mathrm{Si})$ varied between 0.24 to $1.44 \mathrm{mmol} \mathrm{Si} \mathrm{m}^{-2} \mathrm{~d}^{-1}$ and were lowest in the AG and highest on the left side of the

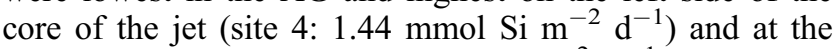

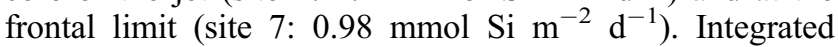

production ratios $(\Sigma \rho \mathrm{Si} / \Sigma \rho \mathrm{C})$ were generally much lower than $\Sigma \mathrm{BSi} / \Sigma \mathrm{PC}$ stock ratios and were comprised between 0.01 and 0.05 , except for site 8 where the $\Sigma \rho \mathrm{Si} / \Sigma \rho \mathrm{C}$ ratio (0.08) was significantly higher than the $\Sigma \mathrm{BSi} / \Sigma \mathrm{PC}$ ratio (0.01) (Figures 7 and 8). Intermediate values were found at the frontal limit (0.05), but should be considered as a minimum estimate as $\Sigma \rho \mathrm{Si}$ was probably underestimated at this site (see preceding paragraph). $\Sigma \rho \mathrm{Si} / \Sigma \rho \mathrm{C}$ ratios decreased toward the AG where they reached a minimum value $(0.01)$.

\subsection{Export Fluxes of Particulate $\mathrm{Si}, \mathrm{C}$, and $\mathbf{N}$}

[23] The mean daily export fluxes for BSi, PC, and PON, obtained from the sediment traps data, were calculated at 100 and $300 \mathrm{~m}$ depth (Figure 9). A common feature for 

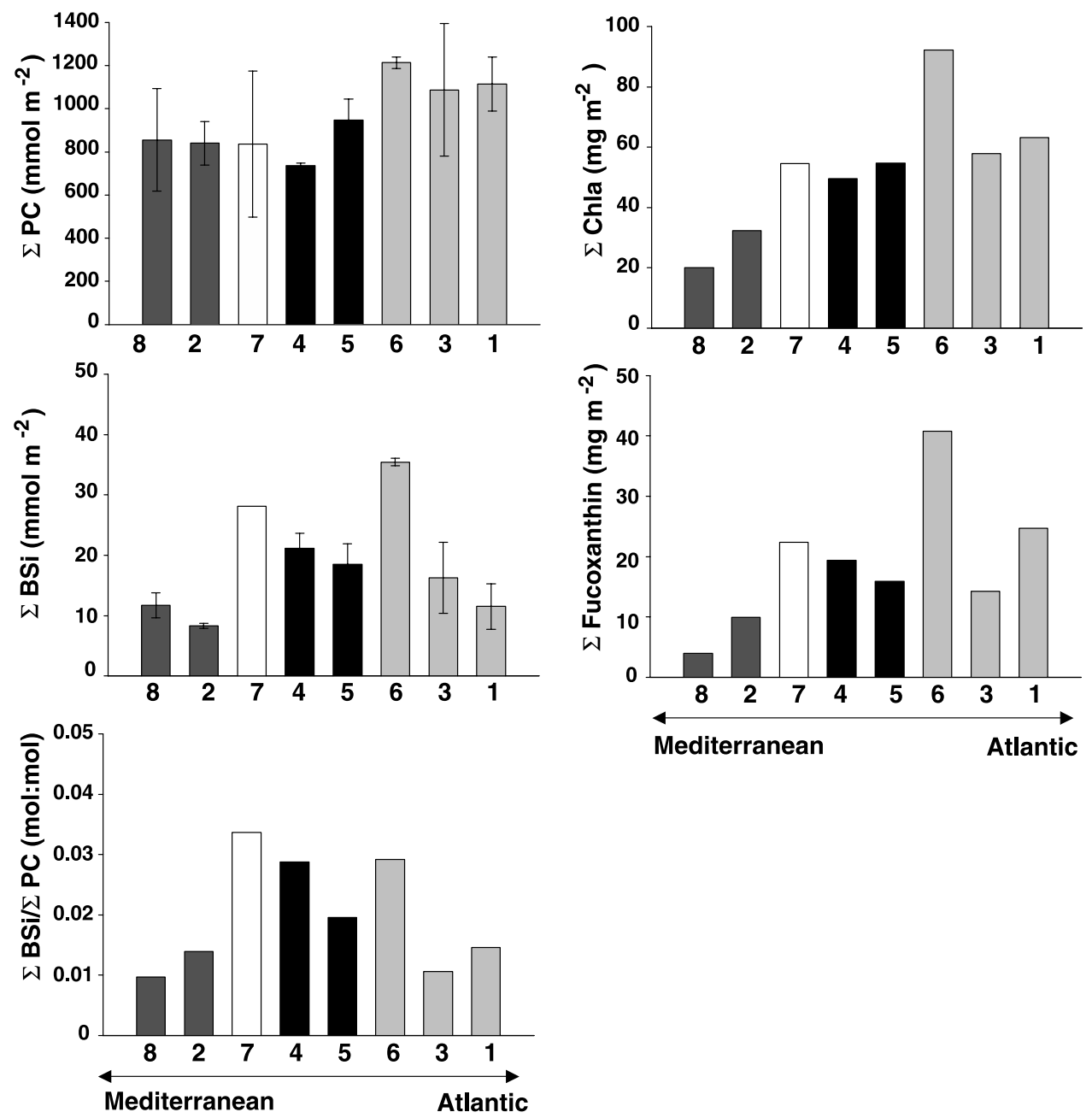

Figure 6. Integrated particulate matter distribution over $200 \mathrm{~m}$ : particulate carbon and biogenic silica in mmol $\mathrm{m}^{-2}$, chlorophyll $a$ and fucoxanthin in $\mathrm{mg} \mathrm{m}^{-2}$, and BSi/POC ratios. Shading represents the different zones first described in Figure 2.

every parameter was the very low fluxes at $100 \mathrm{~m}$ at the frontal limit (site 7), despite high integrated stocks (Figure 6) and high integrated productions (Figure 8). The export flux increased regularly across the front toward the $A G$ where the highest fluxes were recorded, with a significant maximum at site 6 . The increase between site 7 and site 6 ranged from a factor 20 to 29 for biogenic matter (BSi, PC, PON). Export was low at the Mediterranean sites, yet site 2 exhibited higher fluxes than site 8, corresponding to higher integrated stocks. Export fluxes of particulate $\mathrm{Si}, \mathrm{C}$, and $\mathrm{N}$ were considerably lower at $300 \mathrm{~m}$ according to increased remineralization rates with depth. However, at site 1, the PC export flux was higher at $300 \mathrm{~m}$ than at $100 \mathrm{~m}$. This deep increase, only visible on PC fluxes, paralleled the high abundance of foraminifers observed in this particular trap sample (N. Leblond, LOV, Villefranche, personal communication, 2002). Since total particulate carbon measurements (from non-acidified samples) have been performed, it is likely that these zooplanktonic calcareous organisms were responsible for the increase of the $\mathrm{PC}$ flux. The variability range of export fluxes at 100 and $300 \mathrm{~m}$ for $\mathrm{BSi}, \mathrm{PC}$, and PON are reported in Table 2.
[24] $\mathrm{Si} / \mathrm{C}$ and $\mathrm{C} / \mathrm{N}$ molar ratios of the sedimenting material, referred to as $\mathrm{Si} / \mathrm{C}_{\text {sed }}$ and $\mathrm{C} / \mathrm{N}_{\text {sed }}$, are reported in Figure 10. The intersite variability of particulate matter composition increased with depth, as evidenced by a larger range of variations of the molar ratios at $300 \mathrm{~m}$ than at $100 \mathrm{~m} . \mathrm{Si} / \mathrm{C}_{\text {sed }}$ ratios were rather elevated at $100 \mathrm{~m}$ and ranged between 0.09 to 0.20 , with higher values on the Atlantic side of the jet (sites 1 to 5) than at the frontal limit and at the Mediterranean sites. Surprisingly, the $\mathrm{Si} / \mathrm{C}_{\text {sed }}$ ratios decreased with depth, with lower values noticed at $300 \mathrm{~m}$ at all sites (0.01 to 0.17$)$, except at site 2, where the $\mathrm{Si} / \mathrm{C}_{\text {sed }}$ ratio increased slightly. A sharp decrease of the $\mathrm{Si} / \mathrm{C}_{\text {sed }}$ ratio between the top and the bottom traps was particularly visible in the $\mathrm{AG}$ and on the right side of the jet core (sites 1, 3, 6, 5) as well as at the frontal limit (site 7). The $\mathrm{C} / \mathrm{N}_{\text {sed }}$ ratios ranged from 5.0 to 8.4 at $100 \mathrm{~m}$, with higher values at the frontal limit and in the Mediterranean waters (6.2-8.4) as compared to Atlantic waters (5.0-5.9). At $300 \mathrm{~m}, \mathrm{C} / \mathrm{N}_{\text {sed }}$ ratios increased at all sites, ranging from 6.0 to 11.9 , except on the Mediterranean side of the jet, where the ratios were not significantly different between the two collection depths. A strong increase of the $\mathrm{C} / \mathrm{N}_{\text {sed }}$ ratio 


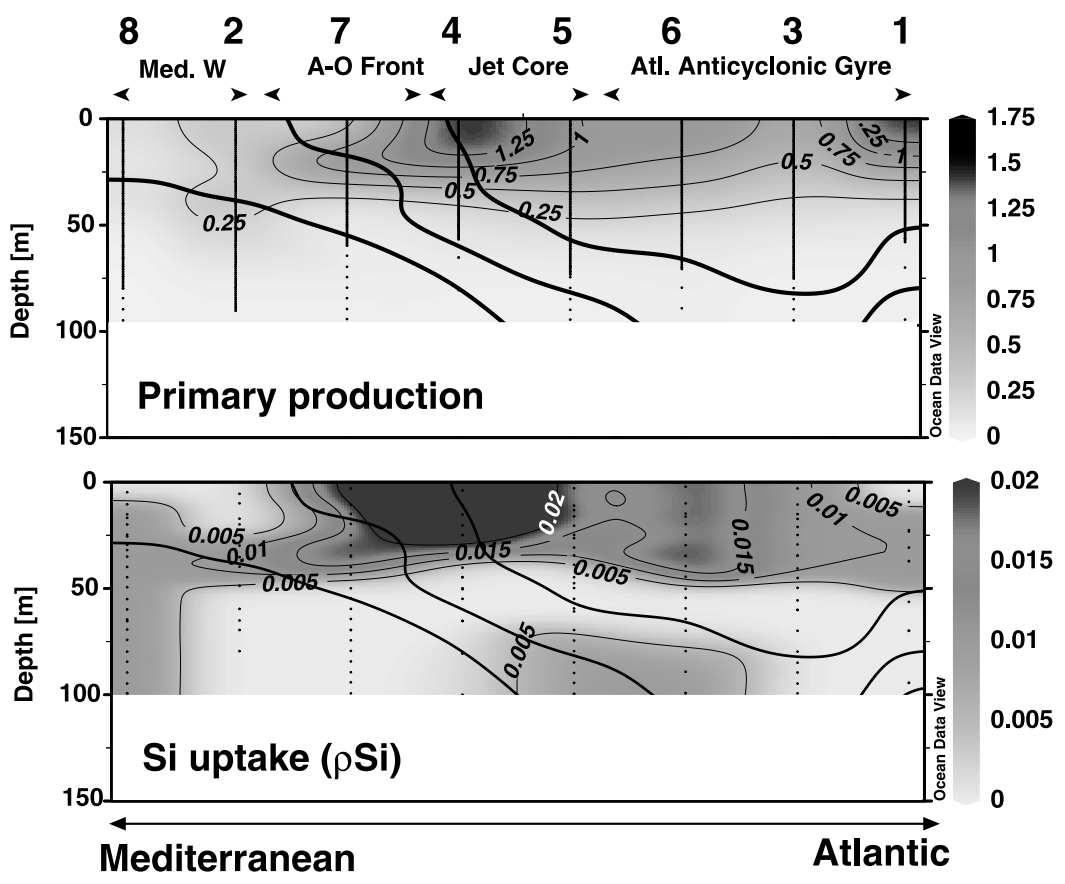

Figure 7. Vertical contour plots of primary $\mathrm{C}$ production profiles $\left(\rho \mathrm{C}\right.$ in $\left.\mu \mathrm{mol} \mathrm{C} \mathrm{L}^{-1} \mathrm{~d}^{-1}\right)$ and Si uptake

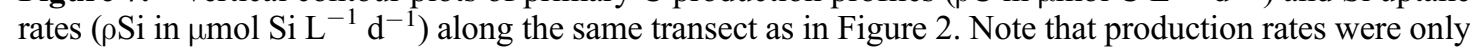
measured over $100 \mathrm{~m}$. See color version of this figure in the HTML.

with depth was observed at sites 1 and 5, with values as high as 11.9 and 10.8 , respectively.

\section{Discussion}

4.1. Qualitative Analysis of Suspended Particulate Material and Sediment Trap Material

\subsubsection{Mediterranean Waters}

[25] The Mediterranean sites $(2,8)$ were characterized by the lowest biomass accumulation. The integrated PC stocks were not significantly different from the other sites, while $\Sigma$ fucoxanthin and $\Sigma$ BSi stocks were much lower, indicating a shift in the phytoplankton composition. The integrated $\Sigma \mathrm{BSi} / \Sigma \mathrm{PC}$ ratios were extremely low $(0.01)$ as compared to Brzezinski's ratio for living diatoms of $0.09-0.13$ [Brzezinski, 1985], indicating a very weak contribution of diatoms to the algal biomass. The Mediterranean waters were also characterized by the lowest primary production rates as well as by low $\mathrm{Si}$ uptake rates. However, a deep increase of $\mathrm{Si}$ uptake rates occurred near the bottom and below the euphotic zone (Figure 7). Silicic acid uptake has been shown to be less light dependent than $\mathrm{C}$ uptake, and can still proceed until 1.5 to 2 times the depth at which photosynthesis is stopped [Nelson and Smith, 1991]. This deep Si uptake was reflected by an increase of the integrated production $(\Sigma \rho \mathrm{Si} / \Sigma \rho \mathrm{C})$ ratio (Figure 8 ), which was highest at site $8(0.08)$ and close to Brzezinski's ratio for small diatoms (0.09). This discrepancy between biomass and production ratios may be explained by a very low siliceous biomass, comprised of cells actively taking up silicon. Pigment determination during the first leg indeed demonstrated the dominance of pico- and secondarily nanophytoplankton in the surface layer, while micro- phytoplankton, which was probably diatom-dominated, dominated the floristic assemblage below the pycnocline [Bruyant, 2002]. Despite the low export fluxes recorded, the $\mathrm{Si} / \mathrm{C}_{\text {sed }}$ ratio in the lower trap was equal to the water column integrated production ratio at site 8 (Figures 8 and 10), suggesting rapid sedimentation processes of small diatoms. Closest to the frontal limit, the $\mathrm{Si} / \mathrm{C}_{\text {sed }}$ ratios at site 2 indicated a more detrital siliceous material $(0.13-0.16)$ as water column production and biomass $\mathrm{Si} / \mathrm{C}$ ratios were 1 order of magnitude lower (Figures 6 and 8).

\subsubsection{Frontal Zone}

[26] The frontal limit (site 7) and the core of the jet (sites 4 and 5) characterized the frontal zone and exhibited some common features. The highest diatom contribution to the biomass was found at the frontal limit (site 7) and at the neighboring site on the left core of the jet (site 4), as indicated by the high concentrations of both fucoxanthin and biogenic silica (Figure 5), the elevated contribution of fucoxanthin stocks to Chl $a$ (around 40\%), and the highest $\Sigma B S i / \Sigma P C$ ratios (Figure 6). This was supported by the reported dominance of microphytoplankton $(65 \%$ of the phytoplankton assemblage) in the frontal zone during the first leg of the cruise [Bruyant, 2002; Claustre et al., 2000 ; Striby, 2000]. However, the $\Sigma \mathrm{BSi} / \Sigma \mathrm{PC}$ biomass ratios appeared very low $(0.02-0.03)$ as compared to Brzezinski's ratio $(0.09-0.13)$, but these values masked contrasted situations as they were integrated over $200 \mathrm{~m}$, whereas diatoms accumulated in the first $30-40 \mathrm{~m}$. If calculated over the euphotic layer, the biomass ratio at the frontal limit equaled the production ratio of 0.05 (Figure 8) and was closer to the value for living diatoms. The high relative abundance of nano- and picophytoplankton (45\%) was probably the explanation why $\mathrm{Si} / \mathrm{C}$ ratios did not reach 

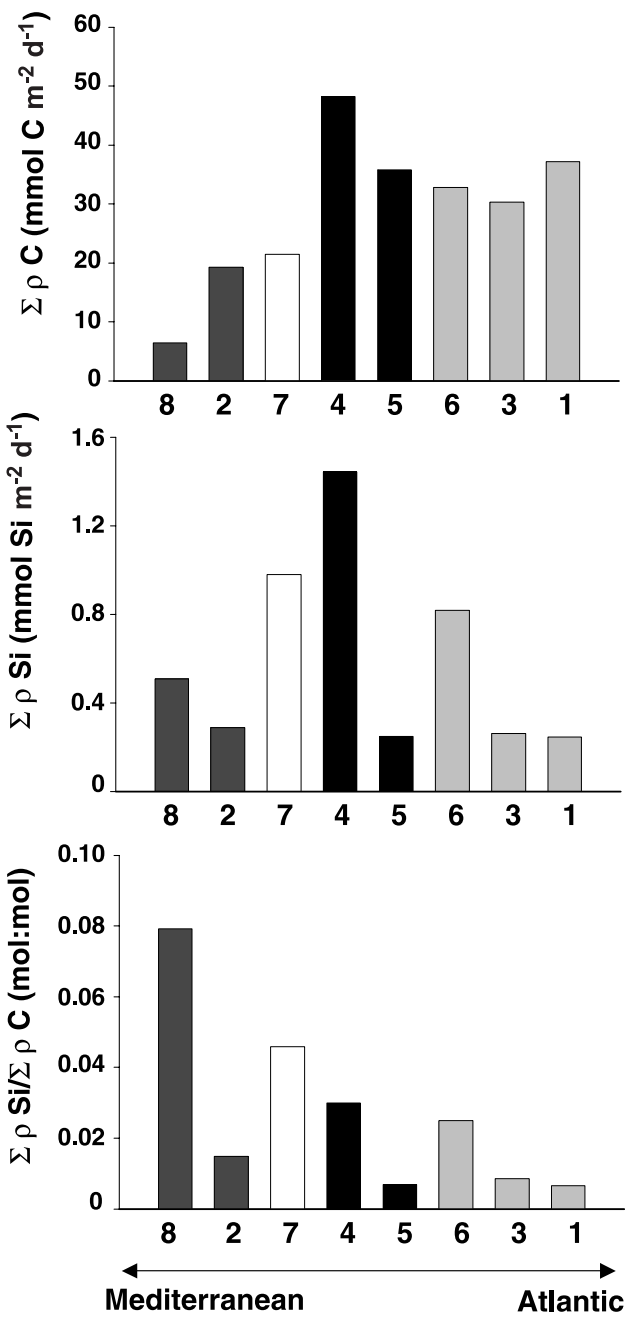

Figure 8. Integrated $\mathrm{C}$ primary production and $\mathrm{Si}$ uptake rates (in $\mathrm{mmol} \mathrm{m}{ }^{-2} \mathrm{~d}^{-1}$ ) over the euphotic layer and $\rho \mathrm{Si} / \rho \mathrm{C}$ ratios. Shading represents the different zones first described in Figure 2.

Brzezinski's ratio. Moreover, a shift in the phytoplanktonic community across the frontal zone was illustrated by the sharp decrease of $\mathrm{Si} / \mathrm{C}$ production ratios from the frontal limit toward the right side of the jet (Figure 8). A similar transition was observed during the Almofront I cruise, where diatoms were dominant at the frontal limit while dinoflagellates dominated the floristic assemblage in the core of the jet [Claustre et al., 1994a]. Several authors also showed a transition between microphytoplankton and nanophytoplankton dominance from the frontal zone toward the AG during Almofront II [Bruyant, 2002; Striby, 2000]. In the upper sediment trap, $\mathrm{Si} / \mathrm{C}_{\text {sed }}$ ratios were lowest at the two productive sites of the frontal limit (sites 7,4 ) and were indicative of living diatoms $(0.09-0.11)$, whereas the $\mathrm{Si} / \mathrm{C}_{\text {sed }}$ ratio was nearly doubled at site 5 (Figure 10 ). This reflected a more detrital siliceous biomass and supported the hypothesis of a decreased contribution of diatoms to production toward the AG. The change in the phytoplankton community (from site 7 toward site 5) was also emphasized by the regular decrease in the upper trap of the $\mathrm{C} / \mathrm{N}_{\mathrm{sed}}$ ratios, usually higher for living diatoms as compared to nanophytoplankton and cyanobacteria.
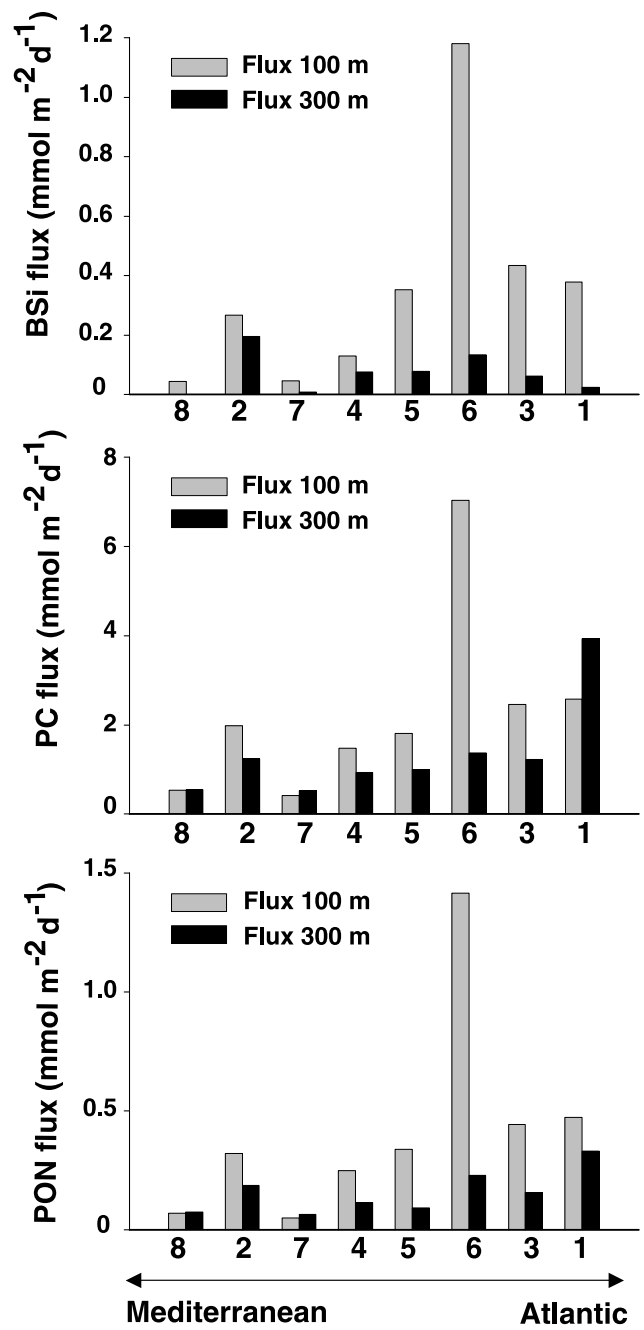

Figure 9. Export fluxes of $\mathrm{BSi}, \mathrm{PC}$, and $\mathrm{PON}$ in $\mathrm{mmol}$ $\mathrm{m}^{-2} \mathrm{~d}^{-1}$ at $100 \mathrm{~m}$ and $300 \mathrm{~m}$.

\subsubsection{Anticyclonic Gyre (AG)}

[27] Some intersite variability was apparent in the anticyclonic gyre, between site 6 , located on the right edge of the cross-frontal transect and near the AG center, and sites 1 and 3 , located upstream (Figure 1b). The cross-frontal export of particulate matter resulted in an accumulation in the center of the AG (site 6), as shown by high values of $\Sigma \mathrm{BSi}, \Sigma \mathrm{Chl} a$, and $\Sigma$ Fucoxanthin (Figure 6) and the increased export fluxes in the upper sediment trap (Figure 9). The more detrital character of the siliceous phytoplankton at site 6 as compared to sites 1 and 3 was illustrated by the higher $\mathrm{BSi} / \mathrm{PC}$ ratios in both the water column and the sediment traps (Figures 6 and 10). Furthermore, the $\mathrm{Si} / \mathrm{C}$ production ratios were extremely low (Figure 8), emphasizing that the accumulating siliceous biomass was in a poor physiological state and that the productive phytoplankton assemblage was dominated by

Table 2. Range Values of BSi, PC, and PON Mean Daily Export Fluxes (in mmol m $\mathrm{m}^{-2} \mathrm{~d}^{-1}$ )

\begin{tabular}{lccc}
\hline & BSi Flux & PC Flux & PON Flux \\
\hline $100 \mathrm{~m}$ & $0.04-1.18$ & $0.4-7.0$ & $0.0-1.4$ \\
$300 \mathrm{~m}$ & $0.01-0.19$ & $0.5-3.9$ & $0.1-0.3$ \\
\hline
\end{tabular}



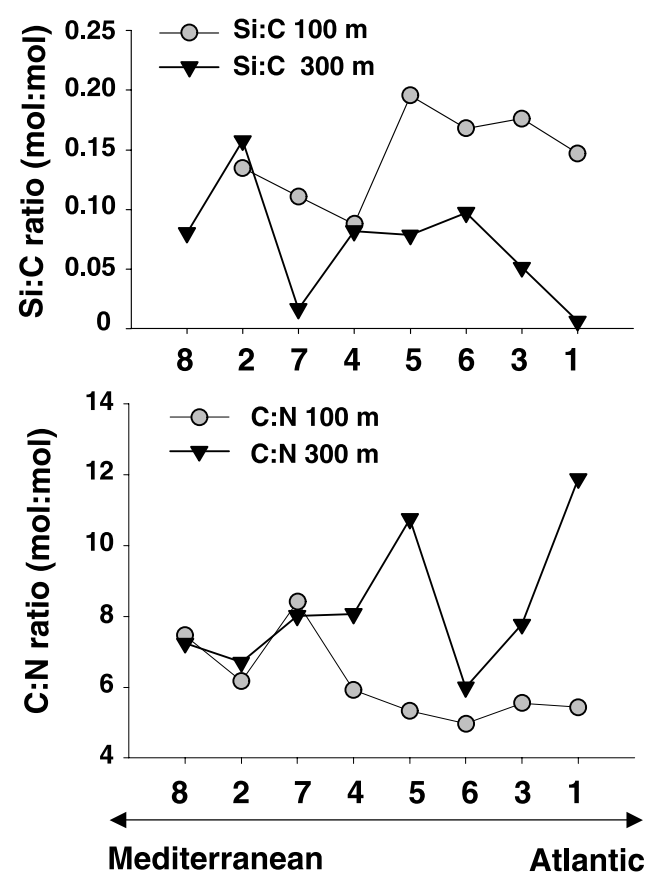

Figure 10. $\mathrm{Si} / \mathrm{C}$ and $\mathrm{C} / \mathrm{N}$ molar ratios of sedimenting material at $100 \mathrm{~m}$ and $300 \mathrm{~m}$.

non-siliceous species. This hypothesis was supported by several authors, who reported the dominance of nano- and picophytoplankton in the AG [Claustre et al., 1994a; Bruyant, 2002; Striby, 2000]. As a general trend, the $\mathrm{Si} / \mathrm{C}_{\text {sed }}$ ratio in the $A G$ decreased in the material collected by the bottom trap (Figure 10), contradicting the current assumption of faster recycling of $\mathrm{C}$ versus $\mathrm{Si}$ down through the water column, as stated in the "silicate pump" model [Dugdale et al., 1995]. It would be very unusual to observe preferential Si loss processes over C in sedimenting material, even if considering a high dissolution term. As this ratio is calculated on the basis of total particulate carbon, we hypothesize that the inorganic carbon fraction increased with depth. Foraminefers were observed in the trap samples at site 1 (which would explain the $\mathrm{Si} / \mathrm{C}_{\text {sed }}$ ratio close to 0 ), but smaller calcareous organisms could have been present in other samples and not detected. If this is true, the increase of the $\mathrm{C} / \mathrm{N}_{\text {sed }}$ ratio with depth could partly be attributed to faster $\mathrm{N}$ remineralization processes through the microbial loop and partly be the consequence of the increasing flux of inorganic carbon.

\subsection{Biomass and Production Limitation Processes}

\subsubsection{Mediterranean Waters}

[28] The Mediterranean waters were highly stratified (shallow $Z_{\mathrm{m}}$ ) and oligotrophic, as underlined by the $1 \%$ PAR level, which reached $60 \mathrm{~m}$ at site 8 . The phytoplankton community was subjected to high irradiance levels [Bruyant, 2002] as $Z_{\mathrm{m}}$ was $<\mathrm{Z}_{\mathrm{e}}$, excluding light as a limiting factor. This shallow stratification caused a severe nutrient depletion of surface waters, which were particularly P-limited, and the subsequent limitation of primary production. As a consequence, the phytoplankton assemblage was dominated by picophytoplankton [Bruyant, 2002; Oubelkheir, 2001] and the lipid analysis reported by
Striby [2000] evidenced a well-developed microbial loop. Below the nutricline, a different community dominated by micro-phytoplankton [Bruyant, 2002; Oubelkheir, 2001] was able to exploit the higher nutrient pool, as evidenced by a slight increase of Chl $a$. The grazing pressure was reduced compared to the Atlantic side of the jet, where the zooplankton biomass was 3 to 4 times more elevated [Youssara and Gaudy, 2001] leading to relatively small export fluxes. Low surface current velocities outside the jet presumably led to weak lateral advection processes, which was supported by the good agreement of $C / \mathrm{N}_{\text {sed }}$ ratios between the surface and the bottom sediment traps. Thus, in this highly stratified and weakly turbulent regime, the diffusive flux at the bottom of the mixed layer appeared to be the principal limiting factor of primary production.

\subsubsection{Frontal Zone}

[29] The frontal zone was characterized by a mesotrophic regime, caused by nutrient upwelling at the frontal limit, due to vertical velocities associated with ageostrophic secondary circulation. The frontal fertilization, indicated by the shallow nutricline, strongly enhanced phytoplankton development as compared to adjacent zones, however confined within a thin mixed layer. A significant BSi and fucoxanthin increase revealed that diatoms were the major contributors to the biomass at this site. The silicic acid drawdown was highest at this site, with a $\mathrm{Si} / \mathrm{N}$ nutrient ratio as low as 0.85 at $15 \mathrm{~m}$, supporting the preferential growth of diatoms. Diatom biomass remained, however moderate, and could result from Si limitation in the mixed layer $(15 \mathrm{~m})$. Indeed, concentrations as low as $1 \mu \mathrm{M}$ of $\mathrm{Si}(\mathrm{OH})_{4}$ together with $\mathrm{Si} / \mathrm{N}$ ratios $<1$ can already be considered limiting for diatom growth [Egge, 1998; Nelson and Dortch, 1996]. The grazing pressure was particularly intense in this area, as indicated by the highest proportion of phytol, a selective index of phytoplankton degradation [Youssara and Gaudy, 2001]. This may partly explain why the frontal limit, which has been reported to be the site of enhanced primary production as compared to adjacent waters, did not exhibit higher integrated stocks. However, the physical lateral transfer of particulate matter between the jet and the AG is also very likely to limit the accumulation of biomass at the frontal limit. This downwelling process can occur along the oblique isopycnals, as the vertical transfer through the density gradient around $27.5 \mathrm{~kg} \mathrm{~m}^{-3}$ is physically weak, and results in the advection of part of the biomass from highly productive zones (A-O Front) to less productive ones (AG). The short-scale variability of biomass was relatively high, as can be seen from the error bars on integrated stocks (Figure 6), emphasizing the importance of advective fluxes in the spatial uncoupling of phytoplankton biomass and new production maximums [Zakardjian and Prieur, 1998].

\subsubsection{Anticyclonic Gyre (AG)}

[30] The anticyclonic system was more oligotrophic in the surface layer as it became more isolated from the jet and more remote from the upwelled nutrient supply. The depth of the mixed layer $\left(\mathrm{Z}_{\mathrm{m}}\right)$ extended below the euphotic layer toward the center of the gyre, homogeneously redistributing the biomass over the $80-$ to $90-\mathrm{m}$ layer. As the siliceous phytoplankton was advected at depth, it probably encountered both light [Bruyant, 2002] and nutrient limitations. At sites 6 and 3, the nutricline was indeed as deep as $80-$ $90 \mathrm{~m}$. The $\mathrm{NO}_{3} / \mathrm{PO}_{4}$ ratio in the euphotic layer (Figure 4) 


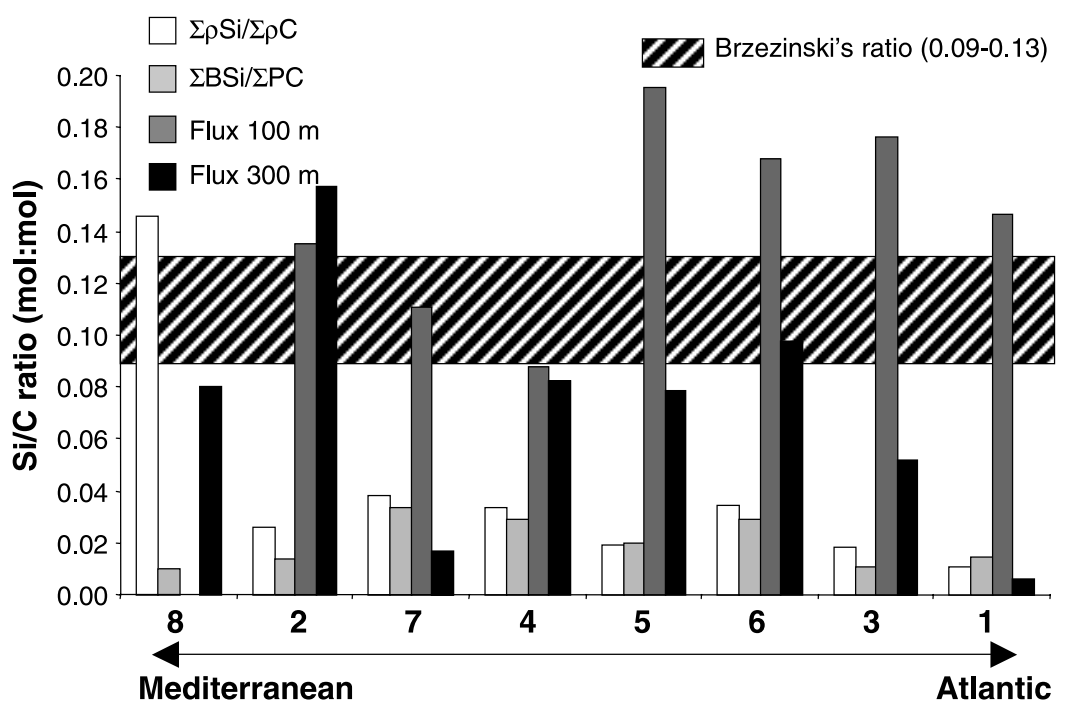

Figure 11. Si/C molar ratios in the production $(\Sigma \rho \mathrm{Si} / \Sigma \rho \mathrm{C})$, stock ( $\Sigma \mathrm{BSi} / \Sigma \mathrm{PC}), 100-\mathrm{m}$ export and $300-\mathrm{m}$ export compartment.

indicated a tendency toward N-limitation of surface phytoplankton. Despite higher integrated biomass, the integrated production rates remained equivalent or lower than those observed in the frontal system. Thus the upper limit to primary production appeared controlled by nutrient and light availability, while biomass accumulation depended on the advection rate from the frontal system.

\subsection{Si and $C$ Uncoupling}

[31] It is now well known that the $\mathrm{Si}$ and $\mathrm{C}$ cycles become uncoupled during export, with rapidly increasing $\mathrm{Si} / \mathrm{C}$ ratios with depth [Officer and Ryther, 1980; Dugdale et al., 1995], due to slower remineralization rate of particulate $\mathrm{Si}$ versus $\mathrm{C}$. The dissolution of siliceous frustules depends on the co-occurrence of high temperatures and bacterial attacks of the protective organic coatings [Lewin, 1961; Bidle and Azam, 1999; Bidle et al., 2002]. The horizontal (intersite variability) and vertical variations of the $\mathrm{Si} / \mathrm{C}$ ratio are shown for the different compartments (production, stock, $100 \mathrm{~m}$ and $300 \mathrm{~m}$ exports) (Figure 11). None of the study sites presented the classical evolution of the $\mathrm{Si} / \mathrm{C}$ ratio, i.e., a constant increase from production to export, as usually observed in other open-ocean systems [Ragueneau et al., 2002]. The $\mathrm{Si} / \mathrm{C}$ stock ratios were, for instance, lower than the $\mathrm{Si} / \mathrm{C}$ production ratios in the frontal zone (sites 7,4 ) and in the Mediterranean waters (sites 8 , 2 ). This may be explained by a rapid loss of $\mathrm{Si}$ in the surface layer due to dissolution processes, or by a stronger increase of integrated $\mathrm{PC}(\Sigma \mathrm{PC})$ as compared to integrated primary production $(\Sigma \rho \mathrm{C})$. By contrast, on the Atlantic side of the jet (sites $5,6,3,1)$, the $\mathrm{Si} / \mathrm{C}$ stock ratios were higher than the $\mathrm{Si} / \mathrm{C}$ production ratios, in agreement with the more detrital character of the siliceous particulate matter accumulated in the anticyclonic gyre. The vertical evolution of the $\mathrm{Si} / \mathrm{C}$ ratios also differed from the classical pattern due to higher $\mathrm{Si} / \mathrm{C}$ ratios in the surface trap than in the bottom trap, previously explained by the presence of foraminifers. Otherwise, the evolution of the $\mathrm{Si} / \mathrm{C}$ ratio from production to $100 \mathrm{~m}$ export was found to be in the range of the results found in other studies. The mean increasing factor of the
$\mathrm{Si} / \mathrm{C}$ ratio between production and $100 \mathrm{~m}$ export was 13.1 (range: 2.4-28.1), slightly higher than the mean value of 9.72 (range: $3-13.8$ ) found for open ocean-systems of the northeast Atlantic or the equatorial Pacific (review given by Ragueneau et al. [2002]). Thus the frontal system appeared more efficient than open-ocean zones in decoupling the $\mathrm{Si}$ and $\mathrm{C}$ cycles through the upper water column.

[32] The relative amounts of BSi and PC reaching each trap, expressed in percentage of the $\mathrm{Si}$ production and primary $\mathrm{C}$ production, respectively, are summarized in Table 3. A very high percentage of the BSi produced in the euphotic layer was exported at $100 \mathrm{~m}$ in the $\mathrm{AG}$, in opposition to the very low percentage of $\mathrm{C}$ export at the same depth, already showing differential sedimentation processes for $\mathrm{Si}$ and $\mathrm{C}$ in the upper layer. The fraction of the produced BSi and PC exported to $300 \mathrm{~m}$ decreased sharply, yet differences remained, with still higher percentages of export for Si. The AG subsystem was actively exporting Si to depth, with 78 to $106 \%$ of the Si production exported to $100 \mathrm{~m}$. At site 6, export exceeded surface production due to the supply of organic matter from the jet along the isopycnes. At the Mediterranean sites, intermediate values were found, with a high percentage of $\mathrm{Si}$ production exported at $100 \mathrm{~m}(53 \%)$ and at $300 \mathrm{~m}(39 \%)$ at site 2 . On the other hand, the frontal zone (sites 7,4$)$ was an area of weak sedimentation, since only 6 to $8 \%$ of the Si

Table 3. Percentage (\%) of the Integrated $\mathrm{Si}$ and $\mathrm{C}$ Production Exported to $100 \mathrm{~m}$ and $300 \mathrm{~m}$

\begin{tabular}{ccccc}
\hline Sites & $\begin{array}{c}\text { BSi Flux } 100 \mathrm{~m} \\
\text { /Si Prod }\end{array}$ & $\begin{array}{c}\text { BSi Flux } \\
\text { /Si Prod }\end{array}$ & $\begin{array}{c}\text { PC Flux } \\
\text { /C Prod } \mathrm{m}\end{array}$ & $\begin{array}{c}\text { PC Flux } \\
\text { /C Prod }\end{array}$ \\
\hline 8 & & 5 & 8 & 9 \\
2 & 53 & 39 & 10 & 6 \\
7 & 6 & 1 & 2 & 2 \\
4 & 8 & 5 & 3 & 2 \\
5 & 52 & 12 & 5 & 3 \\
6 & 106 & 12 & 21 & 4 \\
3 & 78 & 11 & 8 & 4 \\
1 & 92 & 6 & 7 & 11 \\
\hline
\end{tabular}




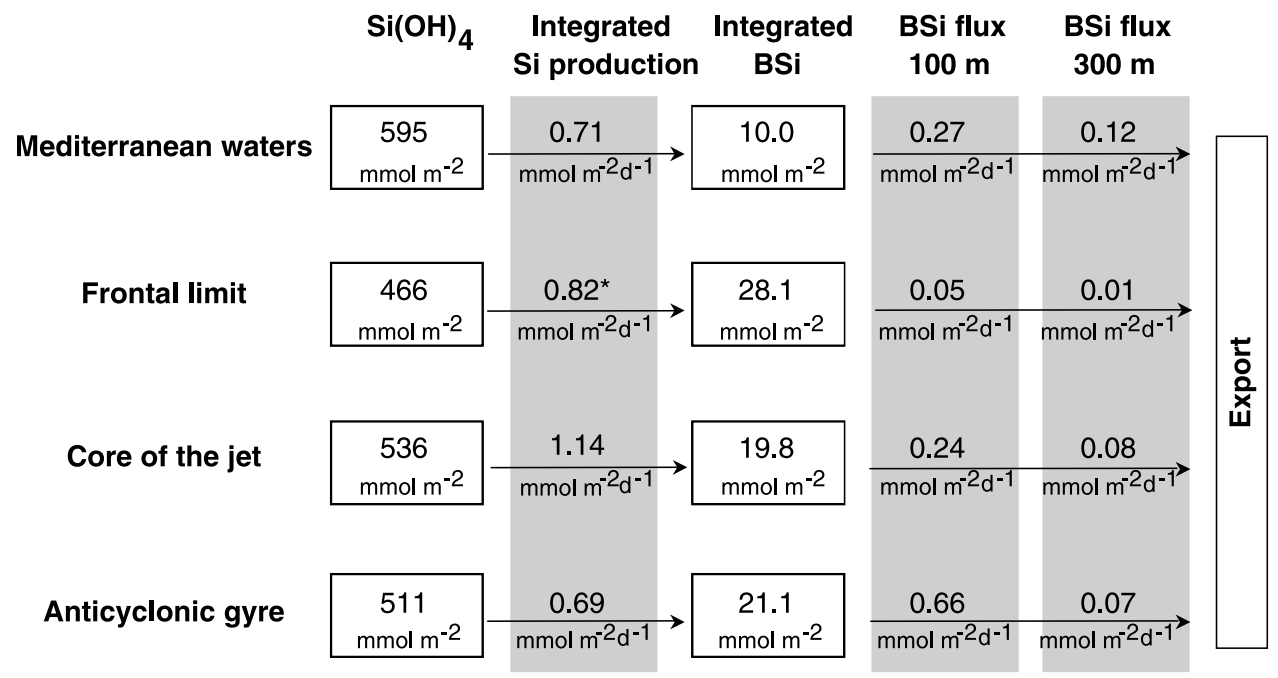

Figure 12. Si budget in the different subsystems of the A-O front system. Boxes represent stock data $\left(\Sigma \mathrm{Si}(\mathrm{OH})_{4}\right.$ and $\Sigma \mathrm{BSi}$ integrated over $\left.200 \mathrm{~m}\right)$, and arrows represent the production and sedimentation $\mathrm{Si}$ fluxes. Si production fluxes were integrated over $100 \mathrm{~m}$. Asterisk: Si production was measured on the second day at the frontal limit (site 7) whereas the dissolved and particulate Si stocks were measured on the first day. Owing to a drift toward a lower biomass area between the two days sampling, the integrated Si production rate is likely to be underestimated.

production was exported to $100 \mathrm{~m}$ (while 1 to $5 \%$ reached the bottom trap). This fraction was even smaller for PC, since an average of $2 \%$ of the primary production was exported to depth. Grazing activity was shown to be highest at the frontal sites [Youssara and Gaudy, 2001], and yet the percentage of produced material exported was considerably lower than at other sites. We therefore emphasize that advective fluxes rather than grazing were probably the main processes setting a limit to the biomass accumulation in the frontal zone. To summarize, it appeared that export was delocalized from the production area in the frontal zone and that the most efficient systems for exporting $\mathrm{Si}$ and $\mathrm{C}$ were the adjacent subsystems, namely the anticyclonic gyre and secondarily the Mediterranean waters.

\subsection{Overview of the Cross-Frontal Exchange of Particulate Matter}

[33] Both horizontal and vertical distributions of biomass and production rates were strongly affected by the hydrological features. Distinct patterns could be observed between the different subsystems: Biomass and production were clearly enhanced by the frontal dynamics on the Atlantic side, while Mediterranean waters exhibited particulate matter concentrations and production rates typical of an oligotrophic regime (Figures 5 and 7). One of the most striking features was the confinement of biomass in the first $35-40 \mathrm{~m}$ at the frontal limit while it extended down to 80$100 \mathrm{~m}$ on the Atlantic side of the jet (Figure 5). This feature has already been described in previous studies of the A-O Front, and similar accumulation of biomass was observed on the lighter (Atlantic) side of the jet [Prieur et al., 1993; Tintoré et al., 1988; Johnson et al., 1989; Claustre et al., 1994a; Videau et al., 1994]; the same trend has also been observed in the Ligurian front [Boucher et al., 1987; Sournia et al., 1990]. This distribution of particulate matter was explained by a cross-frontal downwelling along the isopycnal slopes which shoaled to the surface on the dense
Mediterranean side and deepened toward the right side of the jet [Prieur and Sournia, 1994], resulting in a deeper extension of the nutricline (Table 1). The oblique advective flux occurring at the frontal limit toward the Atlantic side resulted in a deep secondary maximum $(100 \mathrm{~m})$ in the vertical profiles of Chl $a, \mathrm{BSi}$, and $\mathrm{PC}$ on the frontal edge of the AG, a feature already described by Videau et al. [1994] during Almofront I. In our study, the accumulation of diatoms in the AG (site 6), as signed by the relative high values of $\mathrm{BSi}$ and fucoxanthin below $60 \mathrm{~m}$, was found between the same density isopycnals $(27.5-28.0)$ as the maximum observed at $30 \mathrm{~m}$ at the frontal site (site 7). This deep maximum at site 6 also occurs below the euphotic zone, and at a site where primary production is low, which further supports the hypothesis of lateral advection of allochthonous material along isopycnals. The close interaction between the jet and the associated AG was moreover evidenced by the sediment traps results, which indicated a strong decoupling between the productive areas and the sedimentation areas. Export fluxes exhibited a regular crossfrontal increase (Figure 9) from the frontal limit (site 7), where particulate matter was produced, toward the AG (site 6), where it was exported to depth.

\subsection{Silicon Budget and Comparison With Other Oceanic Regions}

[34] A 1-D Si budget was established for each subsystem of the A-O Front (Figure 12), illustrating the average stocks $\left(\Sigma \mathrm{Si}(\mathrm{OH})_{4}\right.$ and $\Sigma \mathrm{BSi}$ over $\left.200 \mathrm{~m}\right)$ and fluxes $(\Sigma \rho \mathrm{Si}$ (over $100 \mathrm{~m}$ ) and export fluxes). The Mediterranean waters were clearly impoverished in BSi, with the lowest average stock $\left(10.0 \mathrm{mmol} \mathrm{m} \mathrm{m}^{-2}\right)$, while waters of the frontal zone and of the AG presented a twofold increase of the BSi stocks $\left(19.8-23.0 \mathrm{mmol} \mathrm{m}^{-2}\right)$. The dissolved Si stock was lower at the frontal limit than in the other subsystems, as a result of enhanced diatom new production and nutrient consumption. The average Si budget for the $\mathrm{AG}$ and the frontal limit 
emphasized the spatial decoupling between the production and the biomass maximums, which was attributed to the strong lateral advection processes occurring in the frontal zone. The most efficient system in exporting $\mathrm{Si}$ was the anticyclonic gyre, with an export flux at $100 \mathrm{~m}$ equivalent to $\mathrm{Si}$ production in the surface layer.

[35] The mean integrated Si production (over $100 \mathrm{~m}$ ) at the A-O Front (average of all sites) amounted to $0.83 \mathrm{mmol}$ $\mathrm{Si} \mathrm{m}^{-2} \mathrm{~d}^{-1}$. The Si production appeared slightly higher (twofold) than the annual average for typical Mediterranean waters off the Gulf of Lions (northwest Mediterranean) estimated to $0.37 \mathrm{mmol} \mathrm{Si} \mathrm{m}{ }^{-2} \mathrm{~d}^{-1}$ [Leblanc et al., 2003]. Yet the integrated production rate found for the A-O Front in the winter season was closest to $\mathrm{Si}$ budgets established for oligotrophic systems (BATS: $\Sigma \rho \mathrm{Si}=0.66 \mathrm{mmol} \mathrm{Si} \mathrm{m}^{-2} \mathrm{~d}^{-1}$ [Nelson and Brzezinski, 1997]) than to that of other frontal zones, which were 1 or 2 orders of magnitude higher [Nelson et al., 1995]. A study conducted in the Western Anticyclonic Gyre in the Alboran Sea in 1997-1998 also reported an order of magnitude higher Si export fluxes on an annual basis, with values ranging from 0.01 to $1.55 \mathrm{mmol} \mathrm{Si} \mathrm{m}^{-2} \mathrm{~d}^{-1}$ at $400 \mathrm{~m}$ depth and from 0.03 to $2.39 \mathrm{mmol} \mathrm{Si} \mathrm{m} \mathrm{m}^{-2} \mathrm{~d}^{-1}$ at $1000 \mathrm{~m}$ depth [Fabres et al., 2002].

\subsection{Seasonal Variations of Diatoms Contribution in the Almeria-Oran Front System}

[36] In this last paragraph, we compare particulate $\mathrm{Si}$ and $\mathrm{C}$ stocks calculated for this study to the ones obtained during the Almofront I cruise, carried out in the A-O frontal system with the same sampling strategy, but in spring conditions (Table 4). During Almofront I (spring 1991), the A-O Front was located in its southernmost position along the $1000-\mathrm{m}$ isobath, due to the collapse of the EAG at the time of the cruise [Prieur and Sournia, 1994]. By contrast, during Almofront II (winter 1997), the EAG was well developed and the A-O Front was located in its median position. During the first cruise, the shoaling of the nitracline in the frontal system induced the fertilization of the frontal zone, resulting in higher integrated stocks in the Atlantic waters than in the Mediterranean ones [L'Helguen et al., 2002; Videau et al., 1994]. Although cell numbers during spring were moderate in the frontal zone, diatoms quantitatively dominated the phytoplankton assemblage and were particularly abundant on the Atlantic side of the jet [Fiala et al., 1994; Videau et al., 1994; Claustre et al., 1994a, 1994b]. This event was characterized as a diatom bloom, due to the quasi-monospecificity and the presence of

Table 4. Comparison of Integrated Stock and Production Values Between the Almofront I Cruise (Spring) and Almofront II (Winter)

\begin{tabular}{|c|c|c|}
\hline Suspended Particulate Matter & $\begin{array}{l}\text { Almofront I } \\
\text { (Spring 91) }\end{array}$ & $\begin{array}{c}\text { Almofront II } \\
\text { (Winter 97) }\end{array}$ \\
\hline$\Sigma \mathrm{Chl} a, \mathrm{mg} \mathrm{m}^{-2}$ & $25-97^{\mathrm{a}}$ & $20-92$ \\
\hline$\Sigma$ Fucoxanthin, $\mathrm{mg} \mathrm{m}^{-2}$ & $0-65^{\mathrm{b}}$ & $4-41$ \\
\hline$\Sigma$ Bsi, mmol m${ }^{-2}$ & $6-50^{\mathrm{a}}$ & $8-35$ \\
\hline$\Sigma \mathrm{POC}, \mathrm{mmol} \mathrm{m}{ }^{-2}$ & $540-1080^{\mathrm{a}}$ & $740-1210$ \\
\hline$\Sigma \mathrm{C}$ Primary production, $\mathrm{mmol} \mathrm{m} \mathrm{m}^{-2} \mathrm{~d}^{-1}$ & $42-150^{\mathrm{c}}$ & $6-48$ \\
\hline$\Sigma \mathrm{BSi} / \Sigma \mathrm{POC}, \mathrm{mol}: \mathrm{mol}$ & $0.015-0.060^{\mathrm{a}}$ & $0.010-0.029$ \\
\hline
\end{tabular}

${ }^{\mathrm{a}}$ Peinert and Miquel [1994].
${ }^{\mathrm{b}}$ Fiala et al. [1994].

${ }^{\mathrm{b}}$ Fiala et al. [1994].

${ }^{\mathrm{c}}$ Videau et al. [1994]. opportunistic (fast-growing) species [Fiala et al., 1994]. The comparison of integrated stocks and primary production values for the two cruises reflected the decreased contribution of diatoms to the phytoplankton assemblage in winter (Table 4). Integrated Chl $a$ were similar for the two seasons, while the fucoxanthin and the BSi stocks were 30 to $38 \%$ lower in winter, confirming the decline of the siliceous component. The diminished abundance of diatoms was further evidenced by the $\Sigma \mathrm{BSi} / \Sigma \mathrm{PC}$ ratios, which were lower by a factor 2 in winter as compared to the spring values. PC integrated stocks were approximately 10 to $20 \%$ higher in winter, while primary production diminished by a factor 3, which suggested either a more important contribution of the heterotrophic compartment or a more detrital biomass. Similar downwelling between the jet and the AG along isopycnal slopes was also observed during spring, but the formal calculation of secondary circulation will be needed to illustrate the lateral convection processes and transport rates. This comparison showed a clear diminution of diatom abundance in the winter season, indicating that the estimated $\mathrm{Si}$ production budget for the A-O front is susceptible to increase drastically during spring.

\section{Conclusion}

[37] The present article was aimed at establishing a $\mathrm{Si}$ budget for the A-O Front in winter 1997 and at investigating the main processes controlling the enhancement of production in the frontal region and the distribution of biomass. The synoptic view of biological processes in the frontal system was achieved through the use of a sampling strategy elaborated to address the mesoscale variability of this highly dynamic system (Frontal group [Prieur and Sournia, 1994]). The frontal system was closely linked to the associated anticyclonic gyre, which accumulated and exported organic matter produced in the frontal zone and in the jet. The new observations of Almofront II, such as $\mathrm{BSi}$, fucoxanthin, and anomalous nutrient distributions at the frontal limit and in the AG, bring clear evidence that the transfer of biological matter from the jet into the AG was supported by secondary circulation processes. Secondary vertical movements occurred on both sides of the jet: Upwelling of nutrients enhanced primary production at the frontal limit, while oblique downwelling occurred along the density isopycnes toward the anticyclonic gyre, inducing a cross-frontal exchange of particulate matter. This induced the aging of the particulate matter from the left side to the right side of the jet and a change in the specific composition of the phytoplankton assemblage, from a diatom- toward a nanoflagellate-dominated community. The nutrient enrichment occurred in a relatively restricted area at the contact zone between Atlantic and Mediterranean waters, but seemed to have a large impact on the trophic regime of the adjacent subsystems. These results emphasized the necessity to consider not only the jet in itself, but also the associated subsystems if accurate production and export budgets are to be estimated.

[38] The winter situation showed lowered primary production rates $\left(6-48 \mathrm{mmol} \mathrm{C} \mathrm{m}^{-2} \mathrm{~d}^{-1}\right)$, representing about one third of the spring production $\left(42-150 \mathrm{mmol} \mathrm{C} \mathrm{m} \mathrm{m}^{-2} \mathrm{~d}^{-1}\right)$. The diatom contribution to the phytoplankton assemblage was dominant in the frontal zone and at the deep Chl $a$ 
maximum in Mediterranean waters but never reached the impressive bloom situation observed by Gould and Wiesenburg [1990] in autumn. Physical gradients appeared stronger in autumn (references given by Fiala et al. [1994]) and could be at the origin of higher secondary vertical movements, thereby enhancing considerably diatom production. The enhancement of Si production by the fertilization of surface waters by the A-O Front was sustained but moderate in the winter season. Production rates were indeed more elevated than Si production measured in oligotrophic Mediterranean waters, but the production budget $(0.83 \mathrm{mmol}$ $\mathrm{Si} \mathrm{m}^{-2} \mathrm{~d}^{-1}$ ) remained closer to that established for oligotrophic mid-ocean gyres than to that of other productive frontal areas.

[39] The variation of thermal gradients as a result of seasonality is expected to have a marked impact on the frontal dynamics and subsequent production and export rates in the A-O frontal system, as strong differences have been observed on the primary trophic level between winter, spring, and autumn conditions. Further studies are still required to quantify annual budgets more accurately in this region of the western Mediterranean Sea, and to determine, for instance, if the 1990 autumn bloom was an exceptional event or a recurrent seasonal feature of the Almeria-Oran frontal system.

[40] Acknowledgments. The Almofront II program was supported by CNRS and Frontal (JGOFS/France) programs. We would like to thank the crew of the $\mathrm{R} / \mathrm{V}$ L'Atalante for their help at sea. We are grateful to J. Fauchot for her work at sea, to N. Leblond for the PC and PON export flux data, to P. Morin for providing the nutrient data, and to Isabelle Vescovali and Jean-Claude Marty for the pigment data for the first leg of the cruise. We are also grateful to the two anonymous reviewers who did a lot to improve the quality of this manuscript.

\section{References}

Allen, J. T., D. A. Smeed, J. Tintoré, and S. Ruiz (2001), Mesoscale subduction at the Almeria-Oran front: I. Ageostrophic flow, J. Mar. Syst., 30, $263-285$.

Arnone, R. A., and P. E. La Violette (1984), Bio-optical variability in the Alboran Sea as assessed by Nimbus-7 Coastal Zone Color Scanner, Tech. Note 283, 26 pp., Naval Ocean Res. Dev. Activ., Univ. of S. Miss., Hattiesburg.

Arnone, R. A., and P. E. La Violette (1986), Satellite definition of the biooptical thermal variation of coastal eddies associated with the African current, J. Geophys. Res., 91, 2351-2364.

Arnone, R. A., and D. A. Wiesenburg (1988), Upwelling irradiance distribution across frontal zones and implications to ocean processes, in Ocean Optics 9, edited by M. A. Blizard, Proc. Soc. Photo. Opt. Instrum. Eng., 925, 124-130.

Arnone, R. A., D. A. Wiesenburg, and K. D. Saunders (1990), The origin and characteristics of the Algerian current, J. Geophys. Res., 95, 1587-1598.

Babin, M., A. Morel, and R. Gagnon (1994), An incubator designed for extensive and sensitive measurements of phytoplankton photosynthetic parameters, Limnol. Oceanogr., 39, 694-702.

Beckers, J.-M., and J. C. J. Nihoul (1992), Model of the Algerian Current's instability, J. Mar. Syst., 3, 441-451.

Bidle, K. D., and F. Azam (1999), Accelerated dissolution of diatom silica by marine bacterial assemblages, Nature, 397, 508-512.

Bidle, K. D., M. Manganelli, and F. Azam (2002), Regulation of oceanic silicon and carbon preservation by temperature control on bacteria, Science, 298(5600), 1980-1984.

Boucher, J., F. Ibanez, and L. Prieur (1987), Daily and seasonal variations in the spatial distribution of zooplankton populations in relation to the physical structure in the Ligurian front, J. Mar. Res., 45, 133-173.

Bower, A. S., and H. T. Rossby (1989), Evidence of cross frontal exchange processes in the Gulf Stream based on isopycnal RAFOS float data, J. Phys. Oceanogr., 19(9), 1177-1180.

Bruyant, F. (2002), Variations circadiennes et spatiales de la photosynthèse: Étude dans différentes conditions hydrologiques et trophiques, Ph.D. thesis, 396 pp., Univ. Pierre et Marie Curie, Paris.
Brzezinski, M. A. (1985), The Si:C:N ratios of marine diatoms: Interspecific variability and the effect of some environmental variables, J. Phycol., 21, 345-357.

Cheney, R. E., and R. A. Doblar (1982), Structure and variability of the Alboran Sea frontal system, J. Geophys. Res., 87, 585-594.

Claustre, H., P. Kerhervé, J. C. Marty, L. Prieur, C. Videau, and J. H. Hecq (1994a), Phytoplankton dynamics associated with a geostrophic front: Ecological and biogeochemical implications, J. Mar. Res., 52, 711-742.

Claustre, H., P. Kerhervé, J. C. Marty, and L. Prieur (1994b), Phytoplankton photoadaptation related to some frontal physical processes, J. Mar. Syst., $5,251-265$

Claustre, H., A. Morel, M. Babin, C. Cailliau, D. Marie, J.-C. Marty, and D. Vaulot (1999), Variability in particle attenuation and stimulated fluorescence in the tropical and equatorial Pacific: Scales, patterns and some biogeochemical implications, J. Geophys. Res., 104, 3401-3422.

Claustre, H., F. Fell, K. Oubelkheir, L. Prieur, A. Sciandra, B. Gentili, and M. Babin (2000), Continuous monitoring of surface optical properties across a geostrophic front: Biogeochemical inferences, Limnol. Oceanogr., 45(2), 309-321.

Dewey, R. K., J. N. Moum, V. A. Paulson, D. R. Caldwel, and S. D. Piera (1991), Structures and dynamics of a coastal filament, J. Geophys. Res., 96, 14,885-14,907.

Dugdale, R. C., F. P. Wilkerson, and H. J. Minas (1995), The role of silicate pump in driving new production, Deep Sea Res., Part I, 42, 697-719.

Egge, J. K. (1998), Are diatoms poor competitors at low phosphate concentrations?, J. Mar. Syst., 16, 191-198.

Fabres, J., A. Calafat, A. Sanchez-Vidal, M. Canals, and S. Heussner (2002), Composition and spatio-temporal variability of particle fluxes in the Western Alboran Gyre, Mediterranean Sea, J. Mar. Syst., 33-34, $431-456$.

Fiala, M., A. Sournia, H. Claustre, J. C. Marty, L. Prieur, and G. Vétion (1994), Gradients of phytoplankton abundance, composition and photosynthetic pigments across the Almeria-Oran front (SW Mediterranean), J. Mar. Syst., 5, 223-233

Fielding, S., N. Crisp, J. T. Allen, M. C. Hartman, B. Rabe, and H. S. J. Roe (2001), Mesoscale subduction at the Almeria-Oran front: II. Biophysical interactions, J. Mar. Syst., 30, 287-304.

Folkard, A. M., P. A. Davies, and L. Prieur (1994), The surface temperature field and dynamical structure of the Almeria-Oran front from simultaneous shipboard and satellite data, J. Mar. Syst., 5, 205-222.

Franks, P. J. S. (1992), Sink or swim: Accumulation of biomass at fronts, Mar. Ecol. Prog. Ser., 82, 1-12.

Gould, R. W., Jr., and D. A. Wiesenburg (1990), Single species dominance in a subsurface phytoplankton concentration at a Mediterranean Sea front, Limnol. Oceanogr., 35(1), 211-220.

Heburn, G. W., and P. E. La Violette (1990), Variations in the structure of the anticyclonic gyres found in the Alboran Sea, J. Geophys. Res., 95, $1599-1613$.

Johnson, K. S., S. W. Willason, D. A. Wiesenburg, S. E. Lohrenz, and R. A. Arnone (1989), Hydrogen peroxide in the western Mediterranean Sea: A tracer for vertical advection, Deep Sea Res., 36, 241-254.

Kerr, R. A. (1986), The ocean's deserts are blooming, Science, 232, 1345.

La Violette, P. E. (1988), Abstracts and agenda: Western Mediterranean Circulation Experiment symposium and workshop, Bay St. Louis, Mississippi, WMCE Newsl., 11, $71 \mathrm{pp}$.

La Violette, P. E. (1989), Western Mediterranean Circulation Experiment (WMCE): A preliminary review of results, Eos Trans. $A G U, 70(31), 746$, $756-757$.

Leblanc, K., B. Quéguiner, N. Garcia, P. Rimmelin, and P. Raimbault (2003), Silicon cycle in the Northwestern Mediterranean Sea: A seasonal study of a coastal oligotrophic site, Oceanol. Acta, 26, 339-355.

Legendre, L., and J. Le Fèvre (1989), Hydrodynamical singularities as control of recycled versus export production in the oceans, in Dahlem Workshop on productivity of the Ocean: Present and Past, edited by W. H. Berger et al., pp. 49-63, John Wiley, Hoboken, N. J.

Lewin, J. M. (1961), The dissolution of silica from diatom walls, Geochim. Cosmochim. Acta, 21, 182-198.

Leynaert, A., D. M. Nelson, B. Quéguiner, and P. Tréguer (1993), The silica cycle in the Antarctic Ocean: Is the Weddell Sea atypical?, Mar. Ecol. Prog. Ser., 96, 1-15.

L'Helguen, S., P. Le Corre, C. Madec, and P. Morin (2002), New and regenerated production in the Almeria-Oran front area, eastern Alboran Sea, Deep Sea Res., Part I, 49, 83-99.

Lohrenz, S. E., D. A. Wiesenburg, I. P. De Palma, K. S. Johnson, and D. E. Gustafson (1988a), Interrelationships among primary production, chlorophyll, and environmental conditions in frontal regions of the Western Mediterranean Sea, Deep Sea Res., Part A, 35, 793-810.

Lohrenz, S. E., R. A. Arnone, D. A. Wiesenburg, and I. P. DePalma (1988b), Satellite detection of transient enhanced primary production in the western Mediterranean Sea, Nature, 335, 245-247. 
McGill, D. A. (1965), The relative supplies of phosphate, nitrate and silicate in the Mediterranean Sea, ICES Mar. Sci. Symp., 18, 737-744.

Morel, A., and J.-M. André (1991), Pigment distribution and primary production in the Western Mediterranean as derived and modeled from coastal zone color scanner observations, J. Geophys. Res., 96, 12,68512,698

Morel, A., D. Antoine, M. Babin, and Y. Dandonneau (1996), Measured and modeled primary production in the northeast Atlantic (EUMELI JGOFS program): The impact of natural variations in photosynthetic parameters on model predictive skill, Deep Sea Res., Part I, 43, 1273 1304.

Nelson, D. M., and M. A. Brzezinski (1997), Diatom growth and productivity in an oligotrophic mid-ocean gyre: A 3-yr record from the Sargasso Sea near Bermuda, Limnol. Oceanogr., 42(3), 473-486.

Nelson, M. D., and Q. Dortch (1996), Silicic acid depletion and silicon limitation in the plume of the Mississippi River: Evidence from kinetic studies in spring and summer, Mar. Ecol. Prog. Ser., 136, 163-178.

Nelson, D. M., and J. W. O. Smith (1991), Sverdrup revisited: Critical depths, maximum chlorophyll levels, and the control of Southern Ocean productivity by the irradiance-mixing regime, Limnol. Oceanogr., 36(8), $1650-1661$

Nelson, D. M., W. O. J. Smith, R. D. Muench, L. I. Gordon, C. W. Sullivan, and D. M. Husby (1989), Particulate matter and nutrient distributions in the ice-edge zone of the Weddell Sea: Relationship to hydrography during late summer, Deep Sea Res., 36, 191-209.

Nelson, D. M., M. A. Tréguer, M. A. Brzezinski, A. Leynaert, and B. Quéguiner (1995), Production and dissolution of biogenic silica in the Ocean: Revised global estimates, comparison with regional data and relationship to biogenic sedimentation, Global Biogeochem. Cycles, 9(3), 359-372.

Officer, C. B., and J. H. Ryther (1980), The possible importance of silicon in marine eutrophication, Mar. Ecol. Prog. Ser., 3, 83-91.

Oubelkheir, K. (2001), Biogeochemical characterisation of various oceanic provinces through optical indicators, over various space and time scales, report, 216 pp., Univ. de la Mediter., CNRS, Verriéres-le-Buisson, France.

Peinert, R., and J.-C. Miquel (1994), The significance of frontal processes for vertical particle fluxes: A case study in the Alboran Sea (SW Mediterranean Sea), J. Mar. Syst., 5, 377-390.

Perkins, H., T. H. Kinder, and P. E. La Violette (1987), Variation of the Alboran Sea Gyre and its relationship to meteorological forcing in the Gulf of Cadiz, Eos Trans. AGU, 68(50), 1725.

Pingree, R. D., P. R. Pugh, P. M. Holligan, and G. R. Forster (1975) Summer phytoplankton blooms and red tides along tidal fronts in the approaches to the English channel, Nature, 258, 672-677.

Platt, T., C. L. Gallegos, and W. G. Harrisson (1980), Photoinhibition of photosynthesis in natural assemblages of marine phytoplankton, J. Mar Res., 38, 687-701.

Prieur, L., and A. Sournia (1994), "Almofront-1" (April-May 1991): An interdisciplinary study of the Almeria-Oran geostrophic front, SW Mediterranean Sea, J. Mar. Syst., 5, 187-203.

Prieur, L., C. Copin-Montégut, and H. Claustre (1993), Biophysical aspects of "Almofront-1", an intensive study of a geostrophic frontal jet, Ann Inst. Oceanogr. Paris, 69(1), 71-86.

Ragueneau, O., N. Dittert, P. Pondaven, P. Tréguer, and L. Corrin (2002) $\mathrm{Si} / \mathrm{C}$ decoupling in the world ocean: Is the Southern Ocean different?, Deep Sea Res., Part II, 49, 3127-3154.

Raimbault, P., B. Coste, M. Boulhadid, and B. Boudjellal (1993), Origin of high phytoplankton concentration in deep chlorophyll maximum (DCM) in a frontal region of the Southwestern Mediterranean Sea (Algerian Current), Deep Sea Res., Part I, 40, 791-804.

Redfield, A. C., B. H. Ketchum, and F. A. Richards (1963), The influence of organisms on the composition of sea water, in The Sea, edited by M. N. Hill, pp. 26-77, Wiley-Intersci., Hoboken, N. J.
Ruiz, J., et al. (2001), Surface distribution of chlorophyll, particles and gelbstoff in the Atlantic jet of the Alboran Sea: From submesoscale to subinertial scales of variability, J. Mar. Syst., 29, 277-292.

Salat, J., J. Castellon, and J. Font (1990), Does the Almeria-Oran front disappear sometimes?, Rapp. P. V. Reun. Cons. Int. Explor. Sci. Mer, 32(1), 173.

Sempéré, R., E. Dafner, F. Van Wambeke, D. Lefèvre, C. Magen, S. Allègre, F. Bruyant, M. Bianchi, and L. Prieur (2003), Distribution and cycling of total organic carbon across the Almeria-Oran front in the Mediterranean Sea: Implications for carbon cycling in the western basin, J. Geophys. Res., 108(C9), 3297, doi:10.1029/2002JC001745.

Simpson, J. H., P. B. Tett, M. L. Argotte-Espinoza, A. Edwards, K. J. Jones, and J. Savidge (1982), Mixing and phytoplankton growth around an island in stratified sea, Cont. Shelf Res., 1, 15-31.

Sournia, A., J.-M. Brylinski, S. Dallot, M. Leveau, L. Prieur, and C. Froget (1990), Fronts hydrologiques au large des côtes françaises: Les sites ateliers du programme frontal, Oceanol. Acta, 13, 413-437.

Striby, L. (2000), Biogéochimie de la matière organique dans deux écosystèmes marins. Cas d'une structure physique unidimensionnelle verticale (mer Ligure) et d'une structure physique frontale (front Alméria-Oran): Variations spatio-temporelles de la fraction lipidique à petite échelle, Ph.D. thesis, 292 pp., Aix-Marseille II Univ., Aix en Provence, France.

Strickland, J. D. H., and T. R. Parsons (1972), A practical handbook of seawater analysis, Fish. Res. Board Can. Bull., 167, 310.

Tintoré, J., P. E. La Violette, I. Blade, and A. Cruzado (1988), A study of an intense density front in the Eastern Alboran Sea, J. Phys. Oceanogr., 18, $1384-1397$.

Tintoré, J., D. Gomis, S. Alonso, and G. Parrilla (1991), Mesoscale dynamics and vertical motion in the Alboran Sea, J. Phys. Oceanogr., 21, $811-823$

Traganza, E. D., D. G. Redalje, and R. W. Garwood (1987), Chemical flux, mixed layer entrainment and phytoplankton blooms at upwelling fronts in the California coastal zone, Cont. Shelf Res., 7, 89-105.

Tréguer, P., L. Lindner, A. J. Van Bennekom, A. Leynaert, M. Panouse, and M. Jacques (1991), Production of biogenic silica in the Weddell-Scotia Seas measured with ${ }^{32} \mathrm{Si}$, Limnol. Oceanogr., 36(6), 1217-1227.

Videau, C., A. Sournia, L. Prieur, and M. Fiala (1994), Phytoplankton and primary production characteristics at selected sites in the geostrophic Almeria-Oran front system (SW Mediterranean Sea), J. Mar. Syst., 5, $235-250$

Vidussi, F., H. Claustre, J. Bustillos-Guzman, C. Cailliau, and J. C. Marty (1996), Rapid HPLC method for determination of phytoplankton chemotaxinomic pigments: Separation of chlorophyll a from divinyl-chlorophyll a and zeaxanthin from lutein, J. Plankton Res., 18, 2377-2382.

Wiesenburg, D. A., and R. A. Arnone (1986), Bio-optical characteristics of the Almeria-Oran front, Eos Trans. AGU, 67(44), 969

Youssara, F., and R. Gaudy (2001), Variations of zooplankton in the frontal area of the Alboran sea (Mediterranean Sea) in winter 1997, Oceanol. Acta, 24, 361-376.

Zakardjian, B., and L. Prieur (1998), Biological and chemical signs of upward motions in permanent geostrophic fronts of the Western Mediterranean, J. Geophys. Res., 103, 27,849-27,866.

F. Bruyant, H. Claustre, K. Oubelkheir, and L. Prieur, Laboratoire d'Océanographie de Villefranche, CNRS-INSU et Université Pierre et Marie Curie, B.P. 28, F-06238 Villefranche-sur-Mer, France. (flavienne. bruyant@dal.ca; claustre@obs-vlfr.fr; kadija.oubelkheir@csiro.au; prieur@ obs-vlfr.fr)

K. Leblanc and B. Quéguiner, Laboratoire d'Océanographie et de Biogéochimie, UMR 6535 - CNRS, Campus de Luminy, Case 901, F-13288 Marseille Cedex 09, France. (leblanc@com.univ-mrs.fr; queguiner@ com.univ-mrs.fr) 